\title{
THE DIVIDEND AND SHARE REPURCHASE POLICIES OF CANADIAN FIRMS: EMPIRICAL EVIDENCE BASED ON A NEW RESEARCH DESIGN
}

\author{
by
}

Abe de Jong ${ }^{1}$, Ronald van Dijk ${ }^{2}$ and Chris Veld ${ }^{3,4}$

May 1, 2002

Keywords: Dividends, share repurchases, payout decisions, nested logit models, questionnaire data JEL codes: G35, C25, C42

\footnotetext{
${ }^{1}$ Abe de Jong is an Assistant Professor of Finance at the Department of Financial Management at Erasmus University Rotterdam. Part of this research was carried out when Abe de Jong was visiting the Department of Finance at the Florida State University in Tallahassee.

${ }^{2}$ Ronald van Dijk is a senior research analyst at ING Investment Management in The Hague.

${ }^{3}$ Corresponding author. Chris Veld is a Professor of Personal Financial Planning at the Department of Fiscal Economics and a Professor of Finance at the Department of Finance and CentER at Tilburg University, P.O. Box 90153, NL-5000 LE Tilburg, the Netherlands. Tel: +3113-4663257; fax: +3113-4662875; e-mail: C.H.Veld@kub.nl. Part of the research for this project was carried out when Chris Veld was visiting the Faculty of Management at the McGill University in Montreal.

${ }^{4}$ The authors are indebted to Yulia Veld-Merkoulova and Monique de Jong for their excellent research assistance and to the Department of Finance at Tilburg University and the Finance Research Centre at McGill University for their financial support. They also thank Petra Danisevska, Edith Ginglinger, Ameziane Lasfer, Elizabeth Maynes, Auke Plantinga and especially Sean Cleary for helpful comments and suggestions. The paper has also benefitted from comments of participants at the European Financial Management Conference in Paris (June 1999), the Financial Management Conference in Orlando (October 1999), the Northern Finance Conference in Kitchener-Waterloo (October 2000) and of seminar participants at Tilburg University, the University of Groningen, and the Florida State University. The usual disclaimer applies.
} 


\section{THE DIVIDEND AND SHARE REPURCHASE POLICIES OF CANADIAN FIRMS: EMPIRICAL EVIDENCE BASED ON A NEW RESEARCH DESIGN}

We empirically investigate dividend and share repurchase policies of Canadian firms. Our analysis contains two features that are uncommon in finance, while they are encountered in other fields of science. First, we use standard, simultaneous and nested logit models. The non-standard logit models are often used in recreational economics and marketing. By examining different model specifications, we test alternative descriptions of the behavior of decision-makers. Second, we use questionnaire data on firm characteristics. Collecting data by questionnaires is hardly ever done in finance, while it is the mainstream approach in sociology and organization. We have sent a questionnaire to the 500 largest non-financial Canadian companies listed on the Toronto Stock Exchange, of which 191 usable responses were returned. Our results are consistent with a structure in which the company first decides whether it wants to pay out cash to its shareholders or not. In the second stage the firm decides on the form of the payout: dividends, share repurchases or both. Payout is determined by free cash flow. The choice for dividends and repurchases depends on behavioral and tax preferences. Furthermore, the payout is less likely to be dividends if the company has executive stock option plans. Finally, we find evidence for the Brennan and Thakor (1990) model. According to this model the existence of asymmetric information amongst outsiders is associated with a preference for dividend payments over share repurchases. 


\section{Introduction}

The most important strategic decisions that a financial manager has to take are the capital structure and the payout decisions. There is ample empirical evidence on the way financial managers take the capital structure decision (see e.g. Kochhar (1996) and Kochhar and Hitt (1998)). The payout decision has received much less attention. Most of the empirical literature focuses on the most common type of payout, i.e. a dividend. Even though the payment of cash dividends is a common practice for many companies, the dividend puzzle remains a controversial topic in the academic corporate finance literature. This is formulated by Fischer Black (1976) as: "The harder we look at the dividend picture, the more it seems like a puzzle, with pieces that just don't fit together". An alternative for dividend payments is to buy back shares. Until now, most of the literature has looked at the dividend and the share buy-back decisions in isolation ${ }^{5}$. However, the dividend and the share buy-back decision are both consequences of the payout decision. We study this decision on two levels. The first is the strategic level, i.e. the structure of the decision process. On the second level the determinants of the choice within the structure are analyzed. On this second level we study the variables that influence the choice for a payout in general and also for the specific choice of a payout, i.e. dividends, share buybacks (SBBs) or both.

There is a large amount of theoretical literature on dividend and SBB policies ${ }^{6}$. From this literature it can be concluded that free cash flow is an important factor in the payout decision. A company that has funds available for which it does not have positive net present value projects available is likely to pay out these funds. This payout can either be in the form of dividends, as a SBB or both. The most important distinguishing factor between the form of payout consists of taxes. The fact that traditionally dividends were treated less favorably then capital gains in the United States has given rise to the earlier mentioned dividend puzzle. The existence of this puzzle was created by the fact that companies pay taxed dividends on one hand and attract new equity capital in the form of equity issues on the other hand ${ }^{7}$. The question whether taxes a priori lead to an advantage or to a disadvantage for the payment of dividends by Canadian companies is not clear. Canadian corporations enjoy a tax advantage for the receipt of dividends. Canadian individuals enjoy a tax advantage if dividends are received at the same time as capital gains. However, capital gains can be deferred to the future. For this reason individuals, much like in the United States, may still have a preference for

\footnotetext{
${ }^{5}$ The only exception is the paper by Jagannathan, Stephens and Weisbach (2000). They study companies from the United States that increase the total payment to their shareholders in the form of dividends, share buy-backs or both. Jagannathan, Stephens and Weisbach (2000) find evidence for their hypothesis that companies will only opt for dividends if the higher payout is permanent.

${ }^{6}$ See e.g. Allen and Michaely (1995) on dividend payments and Lease et al. (1999) on SBBs.

${ }^{7}$ The Tax Reform Act of 1986, in combination with the 1990 legislation, has decreased the differential treatment in taxation between dividends and capital gains in the United States.
} 
capital gains over dividends (see e.g. Davis and Pinches, 1997 or Ross et al., 1999). Other important factors that distinguish between dividends and SBBs are managerial option plans, the behavioral preference for dividends, asymmetric information between outsiders and the underpricing of shares. Managerial option plans are expected to reduce dividends, because dividends reduce the stock price and therefore the value of the options (Lambert, Lanen and Larcker, 1989 and Fenn and Liang, 2001). Similarly they induce SBBs because they are expected to increase stock prices (see Vermaelen, 1984). The behavioral preference for dividends is based on the theory of Shefrin and Statman (1984). Their theory states that individual investors have a preference for cash dividends over selling part of their stock. Brennan and Thakor (1990) present a model in which shareholders are differently informed about the firm. In this model some shareholders have a greater incentive to be informed about the firm's activities. This leads to a result where stock repurchases are associated with a wealth redistribution from less-informed to more-informed shareholders. Consequently, given that the company wants to pay out cash, more-informed shareholders prefer non pro-rata repurchases and lessinformed shareholders have a preference for cash dividends. A specific reason for a firm to engage in a SBB is that if shares are undervalued, management may consider the firm's own stock as an attractive investment opportunity (see, e.g., Ikenberry, Lakonishok and Vermaelen, 1995).

In our paper we study the dividend and SBB policies of Canadian firms. This country is of particular interest since it is the only other country in the world, next to the United States, where share repurchases often occur. These SBBs, generally have the form of open market repurchases. ${ }^{8}$ Another interesting aspect of the Canadian market is that a large number of firms does not pay dividends ${ }^{9}$. The combination of these two facts lead to an interesting sample that includes companies that only pay dividends, companies that are only engaged in SBBs, companies that are engaged in both and companies that do not pay out any funds.

In our view, corporate finance would benefit from the use of a wider array of methods and data sources to test theories. Each method has its strength and weaknesses. Multiple methods and alternative data sources enhance confidence in the validity of the findings. Consequently, the researcher should be willing to adopt approaches that are relatively uncommon within their own discipline. In this paper we introduce two empirical methods that are uncommon to finance, but have been used successfully in other fields of science. We show that borrowing methods from other fields allows different and, potentially, improved tests of theories. In our case the improvement is achieved in two ways. First, we estimate and compare several standard and non-standard logit models, which

\footnotetext{
${ }^{8}$ See Ikenberry, Lakonishok and Vermaelen (2000) for a detailed discussion of Canadian share repurchase programs.

${ }^{9}$ La Porta et al. (2000) calculate a median dividend payout ratio for Canadian firms of $19.78 \%$. This is one of the lowest dividend payout ratios in their sample of 33 countries. Only the Philippines (10.47\%), Denmark $(17.27 \%)$, Spain $(18.33 \%)$ and South Korea (18.49\%) have lower dividend payout ratios.
} 
provide more precise tests of the managerial decision-making process. The second improvement is the use of questionnaire data, which yields a richer data set than accounting and stock market data . The data give us the possibility to test, for example, agency and underpricing theories as perceived by the managers. Accounting and stock market data are, in general, insufficiently informative in this respect.

We study three types of logit models. First, we use standard logit regressions in order to investigate the determinants of the choice between paying dividends or not, and buying back shares or not. Dividends and share repurchases are studied in isolation. Single logit regressions are commonly used in empirical corporate finance. For example, Jung, Kim and Stulz (1996) use a logit regression to describe the differences between firms that issued equity and bond-issuers. Second, we employ a simultaneous logit model in which we test the same set of determinants, while we now allow for a potential trade-off between dividends and share buy-backs. This second model allows dividends and share repurchases to influence each other and is novel to finance. In economics simultaneous logit models are already applied. ${ }^{10}$ Our third type of logits are nested logit models. With these models we can test why managers choose to pay out or not, and, if they pay out, why they choose dividends, share buy-backs, or both. Nested logit models are not used in finance and are also not commonly used in economics. However, such models can specifically be found in two areas, i.e. recreational economics and marketing. ${ }^{11}$ After the application of the three logit models, we compare the performance of the different models. By comparing these different models we can shed more light on the question whether the company sequentially decides on the payout question and on the form of the payout or whether the firm simultaneously decides on both the payout and on the form of the payout. In addition, the determinants of the payout policies are researched.

Information on the payout policies, firm characteristics and shareholder structure is collected using a questionnaire. This questionnaire consists of simple questions without any explicit reference to the relations that we are interested in. The aim is to measure the explanatory variables in the model. In order to reduce the respondent's bias, we ask multiple questions for some variables and we use the average score. In the field of empirical finance only two studies use a similar method. De Jong

${ }^{10}$ For example, Stratmann (1992) investigates the voting behavior (yes or no votes). Vote trading between legislators in US Congress induces a relation between voting on different amendments and Stratmann applies a simultaneous logit model to discover relations between voting on different amendments.

${ }^{11}$ In recreational economics, for example, Morey, Rowe and Watson (1993) apply a nested logit model the choices of a fisher in Atlantic salmon fishing. First, an individual decides to go fishing, or not. Second, the fisher decides on the location. The probability of going fishing depends, among others, on income, while the location is for example determined by the catch rate of the location. The second area in which nested logits are used is the description of consumer behavior, such as marketing. McCarthy and Tay (1998) model the consumers' choice of make/models of cars and the fuel efficiency class. The make/model choice is mainly determined by size, safety and quality perceptions, while the fuel efficiency choice is determined by, among others, gender, income and age. Ansari, Bawa and Ghosh (1995) test a model in which consumers first decide to make a repeat purchase or the buy another brand, and then, conditional on switching brand, decide on which brand to choose. 
and Van Dijk (2001) empirically investigate the determinants of leverage and agency problems and Ang and Jung (1993) test the pecking order hypothesis related to capital structure decisions. In the latter paper, for example, questionnaires are used to measure asymmetric information and marginal financing preferences. The use of questionnaire data for the measurement of characteristics is mainstream in the organization, sociology and psychology literature. ${ }^{12}$ Using the data of the firm's characteristics we apply our logit regression techniques to determine the relationships. A major advantage of our questionnaire-based approach is that it allows us to use private data. It is important to notice that our approach differs from the approach used in other studies that use questionnaire data. Previous questionnaire studies on dividend policy, by, e.g., Baker, Farrelly and Edelman (1985) and Jog and Srivastava (1994) use questionnaires to obtain data on the relationship between firm characteristics. In our paper the relationships are estimated from the information about the firm characteristics.

The questionnaire was sent to the 500 largest non-financial Canadian firms listed at the Toronto Stock Exchange (TSE). In total 191 usable responses were received (38.2\%). We find that over the year $199741 \%$ of the firms paid dividends and that over the 3 -year period preceding the questionnaire, $35 \%$ of the firms were engaged in at least one share buy-back. The most important results of the standard and simultaneous logit models are that dividend payments are significant and positively related to the existence of tax and behavioral preferences. Dividend payments are also significant and negatively related to managerial option plans. SBBs are significantly positive related to free cash flow and the tax preference for SBBs. They are significantly negative related to the existence of asymmetric information amongst outsiders. Confirming these results, the two-stage logit model shows a significantly positive relation between free cash flow and payout. In the second stage of this model we find a significantly positive relation between dividends and tax and behavioral preferences and between SBB and the tax preferences. Furthermore, we find a negative relation between managerial option plans and dividend payments. This model also shows a strong confirmation of the Brennan and Thakor (1990) model that the existence of asymmetric information between outsiders is associated with a preference for dividend payments over SBBs. A comparison of model selection criteria shows that this third model, the two-stage logit model, is the preferred model.

The remainder of this paper is structured as follows. In section 2 we describe theories that can explain the dividend and share buy-back policies of Canadian firms. In section 3 we discuss the empirical methodology of this paper. In section 4 we describe the data. The empirical results of our analysis are included in section 5. We provide a summary and conclusions in section 6 .

\footnotetext{
${ }^{12}$ For example, Russell and Wells (1994) use questionnaires to measure the happiness of husbands and wives in married couples and aim to explain this measure for happiness. Quality of marriage seems to be the strongest predictor of happiness, followed by neuroticism. The predictors hardly differ between the husband's and wife's happiness. Sapienza and Korsgaard (1996) use questionnaire data from venture capitalists regarding their relations with CEOs of firms in their portfolio. For each characteristic, one to four questions were posed and the
} 


\section{Dividend and share buy-back theories}

\subsection{Introduction}

There are three ways to look at dividend and share buy-back policies. These three ways can be translated into three different models. These models are presented in Figure 1.

[Please Insert Figure 1 here]

The first possibility is to consider both policies in isolation. Some theories explain dividend payments. Other theories explain share buy-backs. This possibility is translated into model I. In this model firms choose whether to pay dividends or not, independently from the SBB decision. They also choose whether to buy back shares or not, independently from the dividend decision. Hence, these two decisions are unrelated. The second possibility is that dividends and SBBs influence each other. The idea is that if a company pays dividends it may decide not to buy back shares and vice versa. In model II we include this possibility. In this model it is investigated whether dividends and SBBs substitute each other. Of course, model I is encompassed by model II. The third possibility is that a company first decides whether it wants to pay back capital to its shareholders. After this decision is taken, the company decides on the method of payment. The payment can be a dividend payment, a share buyback program or a combination of both. This possibility translates itself into model III where it is assumed that management first decides whether to pay out funds or not. If they decide to pay out, then in the second stage the type of payout is determined. Model III describes sequential decisions. The determinants of each of the two decisions are examined. We will keep the distinctions between the payout or no payout and between the dividend and SBB decision in mind when discussing the theories. For each theory we will ask ourselves whether it is only driven by the wish to pay back cash to the shareholders or whether it is also driven by the specific wish to do it by dividend payment or by a buy back program.

\subsection{Theories on dividends and share buy-backs}

In their seminal paper Miller and Modigliani (1961) show that in a perfect and complete capital market the dividend policy of a firm does not affect its value. The underlying idea is that any desired stream of payments can be replicated by the stockholder by purchasing and selling equity. The conclusion that dividend policy is irrelevant in perfect and complete capital markets directly leads to the question whether dividend policy is relevant if market imperfections exist and/or if markets are incomplete. A similar reasoning applies to share buy-backs. These are also irrelevant in perfect and complete capital markets, but they may be relevant if these conditions do not hold.

average score of the questions per firm determines the firm's score of the characteristic. For example, the trust of a venture capitalist in the CEO increases when timely feedback is provided. 
Free cash flow. Free cash flow is the cash flow that remains after all positive net present value projects are undertaken. The residual theory states that a firm will pay out its free cash flow to its shareholders. The direct hypothesis in our model is that the existence of free cash flow induces a payout. The indirect hypothesis is that the existence of free cash flow induces both dividends and share buy-backs. A confirmation of the free cash flow hypothesis would be in line with earlier empirical research by Stephens and Weisbach (1998) and Dittmar (2000) for the United States and Li and McNally (1999) for Canada. Stephens and Weisbach (1998) find that US managers, who announce open market repurchase programs, are more likely to actively buy back shares if they have high expected and unexpected cash flows. Controlling for investment opportunities Dittmar (2000) finds that firms that have large amounts of cash and/or large amounts of cash flow ${ }^{13}$ are more likely to buy back shares. Li and McNally (1999) find that Canadian companies, that buy back shares, have more major shareholders and more free cash flow than companies that do not buy back shares. Nohel and Tarhan (1998) study SBBs in the United States. They find that companies with a low Tobin's Q are more profitable after SBBs than companies with a high Tobin's Q. The low-Q companies are characterized by sales of assets and investments that remain constant. These results confirm that a motive for SBBs is the repayment of excess cash. The reason for this is that the low-Q firms restructure their company by selling assets and by paying out the resulting cash flows to their shareholders.

Overinvestment. According to the overinvestment theory of Jensen (1986) managers aim for expanding their firm. The reason for this is that managers consider a large firm to be more prestigious than a small firm. They will pursue this goal even if they have to accept negative net present value projects. This is obviously not in the interest of the existing shareholders. Black (1976) argues that a potential overinvestment problem can be mitigated by paying dividends, because they reduce the amount of free cash flow. Easterbrook (1984) argues that dividends reduce the overinvestment problem because the payment of dividends increases the frequency with which firms have to go to equity markets in order to raise additional capital. In the process of attracting new equity, firms subject themselves to the monitoring and disciplining of these markets. This lowers agency costs. A share buy-back also reduces the amount of free cash flow, suggesting that potential overinvestment also positively influences share buy-backs. Those firms that are more likely to overinvest should pay out more. However, the managers of such firms will only pay out more if they have an incentive to do so. Therefore, we expect a positive relationship between overinvestment and payout if there is effective governance. Overinvestment also has an indirect relation with both dividends and share buybacks. These indirect relationships are hypothesized to be positive given effective monitoring and effective governance.

\footnotetext{
${ }^{13}$ Dittmar (2000) measures cash flow as the ratio of net income before taxes plus depreciation and changes in deferred taxes and other deferred charges to total assets.
} 
Managerial shareholdings. Managers have a preference not to pay out funds, because they enjoy the discretion over free cash flow. If managers own more shares, they are in a better position to keep funds within the firm (see e.g. Eckbo and Verma, 1994). For this reason we expect a negative relation between payout and managerial ownership. Therefore, the direct hypothesis is that the presence of managerial shareholdings prevents a payout. The indirect hypothesis is that the existence of managerial shareholdings prevents both dividends and share buy-backs.

Transaction costs on the company level. If companies pay dividends and at the same time attract new equity, substantial transaction costs are being made. Of course, this argument also holds for share buy-backs. Therefore, we expect a direct negative relationship between payout and the amount of transaction costs that need to be made to attract new shares. This also leads to negative indirect relations between transaction costs and dividends and between transaction costs and SBBs.

Transaction costs on the stockholder level. An investor who wants to receive a regular income from his security holdings has a choice between buying dividend paying stocks and cashing in the dividends, and buying non-dividend paying stocks and regularly selling a part of his portfolio. For a small individual investor the transaction costs of cashing in dividends may be significantly smaller than the transaction costs associated with selling a part of the stocks ${ }^{14}$. For this reason, a company may have a transaction costs clientele that finds the payment of dividends important. We expect that this holds for firms with relatively many small private investors.

Asymmetric information between managers and outsiders. A major question is whether information asymmetries determine the dividend and SBB decisions. Bhattacharya (1979) and Miller and Rock (1985) argue, as pioneers, that information asymmetries between firms and outside shareholders may induce a signaling role for dividends. They show that dividend payments communicate private information in a fully revealing manner. The most important element in their theory is that firms have to pay out funds regularly. Therefore, a similar reasoning applies to recurrent SBBs. This leads to the direct hypothesis that a larger information asymmetry between managers and outsiders leads to a higher payout. The indirect hypothesis that follows is that a larger information asymmetry induces both higher dividends and more SBBs.

Asymmetric information amongst outsiders. Brennan and Thakor (1990) present a model in which shareholders are differently informed about the firm's activities. In their model there is a fixed cost of collecting information. Therefore, large shareholders will have a greater incentive to become informed about the firm's activities than small shareholders. The result is that stock repurchases will be associated with a redistribution of wealth from small shareholders to large shareholders. For this

\footnotetext{
${ }^{14}$ See e.g. Allen and Michaely (1995).
} 
reason our direct hypothesis is that a majority of the firm's shareholders may prefer dividend payments over $\mathrm{SBBs}^{15}$.

Managerial option plans. Managerial option plans are generally not dividend protected. Murphy (1998) finds that only $1.1 \%$ of stock option plans by US firms are dividend protected. This implies that dividends decrease the value of executive stock options. Therefore, management has an incentive to reduce dividends in order to increase the expected value of their options. Lambert, Lanen and Larcker (1989) study the dividend behavior of 221 US firms just after they adopted managerial stock option plans. Their results show that firms decrease the level of dividends, relative to the level of expected dividends, after the adoption of an executive stock option plan. Fenn and Liang (2001) also find a strong negative relationship between dividend payments and management stock options. Therefore, we hypothesize a negative relation between managerial option plans and dividends. On the other hand, we hypothesize a positive relation between managerial option plans and SBBs. The reason for this is that the announcements of SBBs are associated with an increase in stock prices. In turn, this leads to higher values of executive stock options (see Vermaelen, 1984). This is also confirmed in a study by Dittmar (2000) who finds that firms with a large amount of shares outstanding held in reserve to cover their employee and management stock options are more likely to buy back shares. Jolls (1998) also finds that firms managed by executives with large numbers of stock options will be more likely to repurchase their stock than otherwise similarly situated firms.

Taxes $^{16}$. Taxes are an important market imperfection. Canadian public corporations do not pay taxes on cash dividends received from the investment in another taxable Canadian firm. However, if they receive capital gains from selling the stock, they are taxed at $75 \%$ of the firm's marginal tax rate. In other words, dividends carry an important tax advantage for Canadian public corporations. The taxation of dividends received by Canadian individuals is organized in the following way (see e.g. Davis and Pinches, 1997 or Ross et al., 1999). The dividends received from taxable Canadian corporations are first grossed up with $25 \%$ in order to arrive at the taxable dividend. The outcome is taxed at the marginal federal income tax rate. Then a dividend tax credit of $13.33 \%$ is allowed to be deducted from the federal income tax in arriving at the net federal tax payable. Finally a provincial tax is added to the federal tax. If the individual would receive an income from capital gains instead of

${ }^{15}$ Brennan and Thakor (1990) assume that shareholders are differently informed about the prospects of a firm
due to the fact that the collection of information by investors is costly. They argue that the main difference
between dividends and non-proportionate SBBs is that only non-proportionate SBBs may affect the ownership
structure. This change in rights has implications for each investor's wealth. Consequently, a shareholder has to
decide either to collect costly new information or to run the risk of expropriation of wealth by better informed
investors. The hypothesis is that for these reasons firms are less likely to opt for SBBs when the information
heterogeneity amongst shareholders is larger. Asymmetric information amongst shareholders may have an
indirect effect on dividends. The idea is that a smaller or an absent SBB program may induce a higher dividend
level. Practically all Canadian SBBs are open market repurchases, and hence are non-proportionate SBBs. ${ }^{16}$ The questionnaire was sent out in 1998. For this reason, the description of the Canadian tax system is based on the situation as it occurred in 1998. Later changes in the tax system are not incorporated in this paper. 
from dividends, he would be taxed for $75 \%$ of his marginal tax rate. In Appendix A an example is presented for an Ontario resident who receives Can. \$10,000 of taxable dividends from a Canadian corporation. We also study the case where he receives Can. \$10,000 of capital gains from the sale of Canadian stock instead. In this example, the individual is, for tax reasons, better off with dividends than with capital gains. This is also the normal case for a typical individual Canadian investor (see Davis and Pinches, 1997 and Ross et al., 1999). However, it is important to notice that capital gains can be deferred to the future. If they are deferred far enough into the future, the present value of the capital gains taxes is relatively small. Finally, there is the case of non-Canadian shareholders, such as US holding companies and US private investors. As they don't receive the dividend tax credit, they are better off with capital gains than with dividends. Most Canadian SBBs are open market repurchases. The capital gains realized by the investors in these repurchases are treated as ordinary capital gains ${ }^{17}$. Although capital gains that are realized in an open market repurchase are taxed less favorably for Canadian investors than dividends, they still carry a tax advantage. This tax advantage consists of the fact that an individual investor can decide whether to sell her shares or not. With a dividend payment, all private investors receive a payment that is subject to income tax.

Behavioral finance. Shefrin and Statman (1984) develop a theory of dividends based on the idea that, even if the amount of cash received is the same, it can still make a difference for the investor whether the cash comes in the form of dividends, share repurchases, or in the form of selling part of the investors securities. Their model is not based on utility maximization, but on a behavioral theory. In their theory, investors want dividends because of self control. This argument comes down to investors wanting to restrict themselves from consuming too much in the present. They do not want to dip into capital and, therefore, they only allow themselves to consume current income such as dividends. The effect described by Shefrin and Statman (1984) is especially strong for elderly (retired) investors, as they have less income from labor. For this reason they rely more heavily on income from their securities holdings. Shefrin and Statman (1984) refer to this as the behavioral life cycle $^{18}$.

The undervaluation of the firms shares. Ikenberry, Lakonishok and Vermaelen (1995) argue that an important reason for managers to buy back shares is that their shares are undervalued. Managers consider their own stock as an attractive investment. For this reason, managers of undervalued firms may prefer a share buy-back over paying cash dividends and over no payout. This

\footnotetext{
${ }^{17}$ If the shares are not repurchased on the open market, the situation is more complex. If a Canadian investor is dealing at "arm's length" with the company, the sale is also treated as a capital gain. In other cases, Revenue Canada can treat the SBB as a combination of a "deemed dividend", a capital gain and an untaxed return of "paid-up capital".

${ }^{18}$ Shefrin and Statman (1984) argue that their theory is supported by the outcomes of a study from Lease, Lewellen and Schlarbaum (1976) who find that elderly persons have a stronger preference for dividend paying stocks than younger persons.
} 
theory is confirmed in a number of empirical studies. Dann (1981), Vermaelen (1981) and Comment and Jarrell (1991) find that SBBs are associated with significantly positive abnormal returns. Lakonishok and Vermaelen (1990) and Ikenberry, Lakonishok and Vermaelen (1991) have analysed the long run performance of US companies after SBBs. In these studies a significantly positive long run positive abnormal return is found. This abnormal return is more positive for companies with low market-to-book ratios. Ikenberry, Lakonishok and Vermaelen (2000) find a similar result for Canada $^{19}$. The authors suggest that the abnormal returns can be considered as evidence for the undervaluation theory. The fact that the results are stronger for value stocks gives rise to further support, since these companies can use a SBB as a signal that their stock price is too low. It should be noted, however, that the last mentioned result can also be considered as evidence for the free cash flow theory. A low book-to-market ratio is consistent with a high Tobin's $\mathrm{Q}^{20}$. This result would indicate that companies with low growth opportunities experience positive abnormal returns after a $\mathrm{SBB}^{21}$.

\subsection{A summary of the hypotheses}

In this sub-section we summarize the theories on dividend payments and SBBs. We show how these theories fit in the different models that we test. The three alternative models that managers may use in the payout choice are included in Figure 1 (see sub-section 2.1). Based on the distinction between (un)related dividend and SBB decisions and the sequential payout and type of payout decisions, it is possible to attribute theories and hypotheses to the models. The hypotheses are described in Table 1.

[Please insert Table 1 here]

Direct and indirect hypotheses are distinguished. For example, the existence of free cash flow is hypothesized to lead to a payout. Therefore, there is a direct hypothesis that free cash flow has a positive influence on payout. Because, the payout can either be in the form of a dividend or a SBB, there are also indirect hypotheses that the existence of free cash flow have a positive influence on both dividends and SBBs. The direct hypotheses are included in panel A of Table 1. Columns (2) and (3) reflect models I and II. These columns refer to respectively the dividend decision and the SBB decision. The negative sign for SBBs in column (2) indicates the hypothesized trade-off between the two forms of payout. The negative sign for managerial option plans reflects the hypothesized negative relation between the existence of managerial option plans and the probability of a dividend payment.

\footnotetext{
${ }^{19}$ Lasfer (2000) also finds abnormal returns on the announcement date for the UK (1.64\%) and the rest of Europe $(1.06 \%)$. These returns are significant, but lower than in the US. He also finds a significantly positive long term abnormal performance in the UK. The rest of Europe, on the other hand, shows a negative long run abnormal performance.

${ }^{20}$ Tobin's Q is generally measured as the market-to-book ratio or with a construct that is highly correlated with the market-to-book ratio.

${ }^{21}$ See e.g. the earlier mentioned study of Nohel and Tarhan (1998).
} 
In addition, the dividend choice is positively influenced by the transaction costs on the stockholder level, the perceived tax preference and the perceived behavioral preference. Next to measuring the perceived tax and behavioral preferences, we have also asked for the actual existence of clienteles. For example, we asked for the presence of public corporations amongst the shareholders. If they are heavily presented, the firm has a tax clientele. Other clienteles included are the retired-persons clientele and the small-investor clientele. Their existence can be explained by behavioral finance and transactions costs effects, respectively. In column (3) we see that the direct determinants of SBBs are the trade-off with dividends, underpricing, managerial option plans and the tax preference for SBBs.

Model III is described in columns (4) and (5). First we describe in column (4) the theories that deal with the payout decision. In this column we include free cash flow, overinvestment, managerial shareholdings, transaction costs on the company level and asymmetric information between managers and outsiders. In column (5) we include the single hypothesis that directly refers to the type of payout, i.e. asymmetric information amongst outsiders.

In the second part of Table 1, panel B, both the direct and the indirect hypotheses are included. The indirect hypotheses, which are in parentheses, are all derived from the direct hypotheses. For example, in panel A a direct hypothesis was presented between underpricing and the existence of a SBB (models I and II). As a SBB is one of the forms of payout, there is also an indirect hypothesis between underpricing and payout (model III). The reverse case applies to e.g. free cash flow. In panel A, the existence of free cash flow leads to a direct hypothesis for a payout (model III). This leads to an indirect hypothesis for either form of payout, i.e. a dividend or a SBB (models I and II). For this reason, panel B in Table 1 includes two indirect hypotheses for the relation between free cash flow and dividend payment and SBB.

\section{Methodology}

\subsection{Introduction}

In order to test the theories discussed in section 2, we empirically examine the relevant determinants of payout policies. The empirical methodology should provide information about why managers pay dividends and why they buy back shares. In addition, the methodology should also provide insight into the sequential decision moments with respect to the payout decision. Two requirements are put on our methodology. First, the methodology must allow for different decision-making processes. It should be possible to test three structures, (i) unrelated decisions (i.e. dividend and buy back choice are not related), (ii) simultaneous decisions (i.e. dividend and buy back choices are mutually related), and (iii) sequential decisions (i.e. firms first decide on whether to pay out or not, and thereafter choose between dividends and share buy backs). We use three different logit models to capture these three decision-making processes. The second requirement is that the methodology must allow for a 
comparison of the predictive power of these three logit models. Below we discuss the three logit models and the model selection methods.

\subsection{Logit analyses}

We model the dividend and payout policy as two discrete choices for which we apply several logit models. With such models it can be examined why a firm pays out dividends or not, and why a firm purchases back shares or not. The base case is a two-choice model for each decision. Using a single logit equation we estimate to which extent explanatory variables influence the probability that a firms chooses to pay dividends versus the choice for no dividends. A similar equation is tested for the share repurchase choice. The two decisions are modeled as unrelated decisions, assuming that the dividend and share buy-back decisions are two separate processes. The firm chooses to pay dividends independently of the current SBB policy and vice versa. This approach is used because firms first decide on the form of the payout and only in a later stage they decide on the amount of the payout. In this sense our approach is consistent with decision models for companies on the issuance of debt or equity. ${ }^{22}$ In Appendix B.1 we explain the econometric model and the estimation procedure of single logit equations. It is interesting to note that the two standard single logit models also embody the case in which firms consider the repayment process as two processes with four outcomes, i.e. dividend, SBB, both dividend and SBB and no repayment. The estimation results from the multinomial logit model, which is typically used for this type of choice sets, are almost identical to running standard logit regressions on different pairs of outcomes.

In the two standard logit models we consider the dividend and SBB policy as separate decisions, which do not influence each other. In order to understand the way in which the payout process operates, we should also consider the interactions between the dividend and SBB policies, i.e. simultaneous decisions. In other words, we should examine the potential trade-off between dividends and SBBs. This suggests that the standard logit model should be extended by incorporating a dividend or share buy back variable in, respectively, the share buy back and dividend decision. These adjustments change the model in a structural equations logit model, which is explained in Appendix B.2.

The redistribution of capital to shareholders can also be seen as a process in which first a decision is made whether to pay out money to shareholders or not. The choices are sequential decisions. Correlations between dividends and SBBs can be due to variables that affect both policies. These variables influence the payout. They don't necessarily indicate whether this occurs by a dividend payment or a share repurchase program. Thereafter, conditional on this first choice, a combination of instruments is selected, i.e. dividend payment only, SBB only, or both. Hence, different variables affect the first and second decision. Ben-Akiva and Lerman (1985, Chapter 10)

${ }^{22}$ See e.g. Bayless and Chaplinsky (1991) and Jung, Kim and Stulz (1996). 
argue that the nested logit model is a natural choice to model two-stage decision processes. See Appendix B.3 for a description of this model. The model is based on utility theory and considers the attractiveness of the alternatives in a way that acknowledges similarities between the variables. Stricly speaking, the nested logit model does not require that the actual process is a sequential process. The only requirement is that some variables affect groups of decisions. ${ }^{23}$

\subsection{Comparison of logit models}

The multinomial logit and nested logit model are specifications such that one model is not a constrained version of the other model. This complicates the comparison of the models. The likelihood functions of the two models are, however, well defined. Therefore, several standard methods that make use of the likelihood function, can be employed. The Akaike and Schwarz criteria of model comparisons are widely used and provided in most standard econometric text books, e.g. Judge et al. (1988, pp. 848 and 849). The model with the largest value for a particular criterion is the preferred model. Both criteria are the difference between the log of the maximum likelihood and a penalty function based on the number of estimated parameters. Only the penalty function differs over the two criteria ${ }^{24}$. It is important to take into account the number of parameters. When compared with parsimonious models, complex models, which include more parameters, will generally allow for more potential effects and will therefore generally have smaller modeling error, but larger estimation error. Comparison of the maximum likelihoods without a correction for model parsimony ignores this observation. The same can be concluded for methods that compare the predicted outcome with the actual outcome. Given similar maximum likelihoods or statistics that compare predicted with actual outcomes, we should prefer the more parsimonious model. The reason is that the imposed structure is not too tight compared to the more flexible complex model. Later we will see that our nested logit specification is a more parsimonious model than the multinomial and simultaneous logit model. Hence, if similar maximum likelihoods or predictive power are obtained, then we should prefer the nested logit model.

\section{Data description}

Although theory provides us with numerous potential determinants, many of these firm characteristics are difficult to measure empirically. We employ questionnaire data to measure these determinants. A questionnaire is very useful since it allows us to use private information of the firm's managers. Hence, the data allow us to test theories that cannot be tested with the use of publicly available information like accounting and stock market data. For example, from section 2 it can be concluded

\footnotetext{
${ }^{23}$ See Morey (1997) for a thorough description of the application and estimation of nested logit models.

${ }^{24}$ See Stone (1979) for a discussion of the two criteria.
} 
that the perceived preferences of clienteles play a role. The extent to which managers perceive such a clientele to be present cannot be measured with the use of public data. Other topics that specifically call for the use of private data are asymmetric information related theories, e.g., the model of Brennan and Thakor (1990) and the impact of perceived underpricing of the firm' shares as suggested by Ikenberry, Lakonishok and Vermaelen (1995).

Our questionnaire design should avoid respondents bias in two ways ${ }^{25}$. First, the questionnaire consists of simple questions that only aim to measure the potential determinants. Hence, no questions are included on the relations that are examined. Second, two or three questions for some determinants are included to diversify idiosyncratic errors. We use the average score of the questions that approximate the same determinant. The use of questionnaire data with several questions for one determinant is widely applied in other fields of science, but not in finance. In the field of corporate finance two studies use a similar methodology. First, De Jong and Van Dijk (2001) empirically investigate the determinants of leverage and agency problems for Dutch companies as well as the relations between leverage and agency problems. As in Titman and Wessels (1988) they use structural equations modelling with latent variables. Titman and Wessels (1998), however, use annual report and capital market data, whereas De Jong and Van Dijk (2001), like the underlying paper, use questionnaire data. Second, Ang and Jung (1993) test the pecking order hypothesis related to capital structure decisions. In their paper, questionnaires are used to measure asymmetric information and marginal financing preferences.

The questionnaire was sent out to the 500 largest non-financial Canadian firms listed at the Toronto Stock Exchange ${ }^{26}$. The firms are identified from the Compact Disclosure Canada Database of October 1997. This database covers more than 8,500 Canadian firms. In order to identify the 500 largest firms we used the Report on Business 1000 list of July 1997. We omitted financial firms, i.e. firms with an SIC-code starting with a six (banks, insurance companies, offices of holding companies, brokers, real estate agencies, etc.). We aimed at having the questionnaires filled in by the CFOs of the firms. For this reason we addressed the questionnaire to the CFO if his or her name was included in the data-set. In case we did not have the name of the CFO, we addressed the questionnaire to the CEO of the firm. The list of officers was used to select the CFO (or the CEO, Vice-president Finance, controller, treasurer, or a combination). The questionnaire was anonymous. ${ }^{27}$ Respondents were promised a copy of the research report if they would fill in a separate form containing the name and the address of the respondent. We ensured anonymity by supplying separate return envelopes for the

\footnotetext{
${ }^{25}$ Appendix $\mathrm{C}$ contains the questions of the questionnaire that are used in our analysis.

${ }^{26}$ Firm size was measured by market capitalization.

${ }^{27}$ Advantages of using an anonymous questionnaire are a higher (expected) response rate and a higher possibility of receiving honest answers. A disadvantage is the fact that it is not possible to relate the results to other data on the firm such as accounting variables.
} 
questionnaire and the form for the respondents name, position, and address to obtain the results of the research. The questions deal with firm characteristics such as the presence of managerial option plans, asymmetric information, and the presence of specific clienteles amongst the shareholders. All questions could be answered on a scale from 1 to 7 , or by indicating an answer on an alternative scale. The only exception on this rule were two questions in which we asked for respectively the Earnings Per Share and the Dividends Per Share, based on regular dividends, that the firm paid over the financial year $1997 .^{28}$ The questionnaire was mailed to the 500 firms in May 1998, followed by a second mailing in June 1998 to improve the response rate and reduce potential non-response bias. The questionnaire yielded 191 usable responses (38.2\%). This compares favorably with responses on other surveys. All returned surveys were received within a period of four months from the first mailing.

\section{The results}

In this section the empirical results are discussed. After a discussion of the summary statistics, the results of the individual models are analyzed. This is followed by a comparison of the performance of the individual models. In Table 2 the summary statistics are presented.

[Please insert Table 2 here]

The variable dividend paying in Table 2 is a dummy variable based on the question whether the company has paid a dividend over the year 1997. This dummy is one if the company has paid a dividend over 1997 and zero otherwise. According to Table 2, 41\% of the companies paid dividends and $59 \%$ of companies did not. We also asked whether the company has undertaken a SBB in the three year period preceding the questionnaire ${ }^{29}$. The result of the SBB dummy in Table 2 shows that this was the case for $35 \%$ of the companies. Some of the explanatory variables in Table 2 are measured by two or three questions. This applies for example to the asymmetric information amongst outsiders (questions 18 and 19) and the behavioral preference for dividends (questions 14, 15 and 16) variables $^{30}$. For such variables we present the average of the relevant questions. In Table 2 we also compare the mean and standard deviation of a number of variables between different groups of companies. The standard deviations in Table 2 show that there is a sufficient cross-section variation in

\footnotetext{
${ }^{28}$ We only focus on regular dividends. See DeAngelo, DeAngelo and Skinner (2000) for an analysis of special dividends.

${ }^{29}$ SBBs were measured over the 3-year period preceding the questionnaire. Dividends were only measured over 1997. However, the dividend policy of Canadian firms is very stable over time. From a study of Canadian companies over the period 1995-1997 we find that $97 \%$ of the firms that did not pay dividends in 1997 also did not pay dividends in 1995 .

${ }^{30} \mathrm{~A}$ potential problem of question 16 was that it might have been interpreted as a measure of transaction costs. If transaction costs are high, private persons have a preference to consume from dividends rather than by selling shares. However, we have measured the correlation between questions 14 and 16 and this turns out to be very high. For this reason we have included question 16 as a measure of the behavioral finance construct.
} 
the answers to the various questions. The remainder of Table 2 shows univariate comparisons between the determinants and the payout choice. Since (most of) the results are consistent with those from our logit regressions, we postpone their discussion.

In Table 3 the results of the tests for model I are included. In model I, dividends and share buy-backs are assumed to be unrelated. This model is tested by carrying out single logit regressions. The regression results include both the direct and the indirect determinants.

[Please insert Table 3 here]

The first column of Table 3 provides the coefficients and the $t$-values of the regression in which dividend is explained. We find the expected significant negative relationship between dividend payments and transaction costs on the company level. This means that if transaction costs for companies to attract new equity capital are high, they pay less dividends. We also see that companies that have managerial option plans are less likely to pay dividends. This is also in line with our expectations, since most managerial option plans are not dividend protected. The significantly positively sign between dividends and the tax preference for dividends, indicates that there is a clientele that favors the management of the company to payout dividends for tax reasons. In section 2 we saw that, from a tax point of view, dividends are an attractive form of payout for Canadian companies and Canadian private persons. Finally, there is an expected significantly positively relationship between dividend payments and the behavioral preference for dividends. This means that the company has a clientele that wants the management to pay out dividends for behavioral reasons. More importantly, it means that the management of the company adjusts its payout policy according to the desires of this clientele. The existence of different clienteles, including a tax clientele, was also found in a questionnaire study by Baker, Farrelly and Edelman (1985).

The second column in Table 3 provides the determinants of the share buy-back decision. We find the expected significantly negative sign for the variable asymmetric information amongst outsiders. We also find the expected significantly positively parameter estimate for free cash flow. This confirms the theory that if a firm has free cash flow, it is more likely to buy back its shares. This is also in line with previous empirical evidence by e.g. Stephens and Weisbach (1998), Li and McNally (1999) and Dittmar (2000). In addition, we find the expected significantly positively sign between share buy-backs and the tax preference for share buy-backs. A possible explanation for this is that some Canadian firms are dominated by US shareholders who have a preference for capital gains for tax reasons (see section 2). Besides that, the tax advantage for SBBs can also be based on the fact that in case of a SBB a party can decide itself whether to sell shares, and thus cash in capital gains, or not. This offers an advantage compared to dividend payments where shareholders do not have such a choice. Underpricing shows the expected positive coefficient. However, contrary to e.g. Ikenberry, Lakonishok and Vermaelen $(1995,2000)$ we do not find a significant effect. There are some potential explanations for this difference in results. First, we only measure whether underpricing 
occurs for a longer period. It can be the case that companies want to profit from a short term undervaluation. The second possibility is that a company has decided to buy back shares, for example because of the existence of free cash flow, and that it chooses the right moment to do so, i.e. when shares are undervalued. The third possibility is that the underpricing effect found in earlier studies can (partly) be explained as a free cash flow effect (see section 2.2).

Appendix D contains the results of the multinomial model which is mathematically identical to the single logit models (see section 3 ). The estimation gives similar results.

In Table 4 the results of the tests for Model II are included. In model II dividends and share buy-backs are assumed to influence each other. This model is tested by carrying out simultaneous logit regressions.

[Please insert Table 4 here]

The estimates for the coefficients dividend paying and share buy-back are not significant. This would indicate that the decisions do not influence each other. The remaining results in Table 4 are comparable to the single equation logits in Table 3. Furthermore, it can be noticed that the signs of the coefficients do not change compared to model I in Table 3 . The magnitude of the $t$-statistics decreases in most cases. First, this can be due to the fact that model II is less parsimonious than model I. This would indicate that model I gives a closer representation of the decision process than model II. Second, the more complex estimation method can be less efficient in finite samples.

In Table 5 the results for model III are included. Model III is the nested logit model in which the firm decides in the first stage whether to pay out and in the second stage on the form of the payout.

[Please insert Table 5 here]

The first column in Table 5 is labelled "no payout" and it presents the determinants for the payout choice. These are the direct hypotheses for the payout decision that are included in panel A of Table 1 (model III in column (4)). Free cash flow has the expected significantly negative sign, indicating that the existence of free cash flow makes it less likely that the firm will not pay out funds. Column (2) presents the influence of the direct hypothesis on the payment of dividends (see column (1) in panel A of Table 1). In addition we include the only variable that distinguishes between the type of payout, i.e. asymmetric information amongst outsiders. A significantly negative coefficient is found for managerial option plans. This means that the existence of an executive stock option plan makes it less likely that the firm pays dividends. This finding is consistent with an earlier empirical study for the United States by Lambert, Lanen and Larcker $(1989)^{31}$. We find significantly positive results for the behavioral preference for dividends. This is in line with the Shefrin and Statman (1984) model. Furthermore, it can be noticed that there is a significantly positively result for the tax preference of dividends. Apparently, the choice for the type of payout is influenced by the tax clientele of the firm.

\footnotetext{
${ }^{31}$ See sub-section 2.2 .
} 
Table 5 also shows that the actual clienteles do not give significant results. In column (3) of Table 5, the direct hypotheses on the existence of SBBs are presented (based on column (2) in panel A of Table 1). This column also includes asymmetric information amongst outsiders. First, we see that the choice for SBBs is influenced by the tax preference for SBBs. Asymmetric information amongst outsiders shows the expected negative sign in the third column. This result can be explained using the model of Brennan and Thakor (1990). In this model, shareholders are differently informed about the firm's activities. The model assumes that there is a fixed cost for collecting information. This leads to a situation where large shareholders will have a greater incentive to become informed about the firm's activities than small shareholders. Consequently, SBBs are associated with a redistribution of wealth from small to large shareholders. The reason for this is that large shareholders know in which SBBs to participate and small shareholders do not. In Table 5 we find that if there is a large information asymmetry amongst shareholders, firms are more likely to pay dividends than to buy back shares. This is consistent with the model of Brennan and Thakor (1990).

In Table 6 the fit of the models is compared.

\section{[Please insert Table 6 here]}

Table 6 can be read as follows. If we first look at the results of the separate logit models (model I) in panel A, we see that in total 45 companies only paid dividends. The separate logit models correctly predict 27 of these companies $(60 \%)$. In four cases the model incorrectly predicts that the company both pays dividends and carries out a SBB, while actually only dividend was paid. Also, in 14 cases the model incorrectly predicts that the company will not pay out at all. The numbers on the diagonals are the correct predictions. It can be seen that the separate logit model especially does a good job in predicting companies that only pay dividends and companies that do not pay out at all. The sum of the diagonals is 98 , indicating that $56 \%$ of the observations are correctly predicted. Note that without any information, this would be about $25 \%$. The simultaneous logit model (model II) approximately shows the same results. In section 3 we have argued that the separate logit model (model I) can be rewritten as a multinomial model. The findings with regard to the number of correct predictions are similar for the separate logit model and the multinomial logit model.

Since the multinomial model is similar to the two single logit models and the simultaneous model has no added value, we are left with the question whether we should prefer the multinomial logit or the nested logit model. The performance of the two models can be compared using measures of fit. In section 3 we have already argued that there are three well-known measures of fit: the likelihood criterion, the Akaike Information (AIC) criterion and the Schwarz criterion. The major advantage of rewriting model I to the multinomial model is that for this model the three criterions can be compared to that of the nested logit model, since the likelihood function is known for the multinomial model. In section 3 we also argued that the model with the highest value for the AIC and Schwarz measures is the preferred model. Panel B of Table 6 shows that for both measures the nested 
logit model is the preferred model. The nested logit model imposes much more structure on the problem in terms of less parameters, which is not translated into a lower value of the likelihood function. This is remarkable. In short, our analysis shows that the nested logit model is the preferred model to explain dividend and SBB policies.

\section{Conclusion}

In this paper we have tested three models for dividend and share buy-back (SBB) policies. In the first model dividends and SBBs are studied in isolation. In the second model dividends and SBBs influence each other. The third model assumes that a firm first decides whether it wants to pay out cash to its shareholders or not. After this decision is taken, the company decides on the form of the payout: dividends, SBBs or both. The methodology that we use consists of two steps: in the first step we measure firm variables. In the second step we measure the relationships between the variables. The variables were collected using a questionnaire, which was sent to the 500 largest non-financial companies on the Toronto Stock Exchange. The final analysis was carried out on the 191 usable responses that we received.

We find strong empirical evidence for the third model in which the company first decides on the payout question and then on the form of the payout. The payout decision is driven by the existence of free cash flow. The choice for dividend as payout is caused by factors such as tax and behavioral preferences. The choice for SBBs is driven by tax preferences. We also find evidence that the payout for firms with managerial option plans is less likely to be dividends. Finally, our analysis shows a strong confirmation for the Brennan and Thakor (1990) model. This model states that the existence of asymmetric information amongst outsiders is associated with a preference for dividends over SBBs.

In addition to the test of payout theories and the evidence for Canadian firms, an important contribution of our analysis to the empirical finance literature is the application of two features within our empirical approach that are novel to finance, but that are common approaches in other fields of science. The first feature is the use of a variety of logit models: standard single-equation specifications, a simultaneous logit model and nested logit models. The latter type is common in recreational economics and marketing. Each of the econometric models is linked to a particular

hypothesis on the decision structure. By comparing the explanatory power of the models we obtain a more accurate description of the decision-making process. The second novel method is the use of questionnaire data about characteristics. This type of data is hardly ever used in finance, while researchers in sociology and organization often apply this method. Our results illustrate that the advanced logit modeling indeed allows a more precise test of theory and a closer description of empirical regularities. Moreover, our large set of relevant variables clearly demonstrates the possibilities that questionnaire data offers to researchers in finance. 


\section{References}

Allen, F. and Michaely, R.: "Dividend policy", in: R. Jarrow, V. Maksimovic and W.T. Ziemba (eds.), Finance, Handbooks in Operations Research and Management Science, vol. 9, NorthHolland, Amsterdam, 1995, page 793-837.

Amemiya, T.: "The estimation of a simultaneous-equation tobit model", International Economic Review 20, 1979, page 169-181.

Ansari, A., Bawa, K., and Ghosh, A.: "A nested logit model of brand choice incorporating varietyseeking and marketing-mix variables", Marketing Letters 6, 1995, 199-210.

Ang, J.S.: "Do dividends matter? A review of corporate dividend theories and evidence", Salomon Brother Center for the Study of Financial Institutions, Monograph Series in Finance and Economics, Monograph no. 2, 1987.

Ang, J.S. and Jung, M.: “An alternative test of Myers' pecking order theory of capital structure: The case of South Korean firms", Pacific-Basin Finance Journal, 1993, page 31-46.

Baker, H.K., Farrelly, G.E., and Edelman R.B.: "A survey of management views on dividend policy", Financial Management, 1985, page 78-83.

Bayless, M.E. and Chaplinsky, S.: "Expectations of security type and the information content of debt and equity offers", Journal of Financial Intermediation, 1991, page 195-214.

Ben-Akiva, M., and Lerman, S.: "Discrete choice analysis: theory and applications to predictive travel demand", MIT Press, Cambridge (MA), 1985.

Bhattacharya, S.: "Imperfect information, dividend policy and "the bird in the hand" fallacy", Bell Journal of Economics 10, 1979, page 259-270.

Black, F.: "The dividend puzzle", The Journal of Portfolio Management, 1976, page 5-8.

Brennan, M.J. and Thakor, A.V.: "Shareholder preferences and dividend policy", The Journal of Finance, 1990, page 993-1018.

Comment, R. and Jarell, G.A.: "The relative signalling power of Dutch-auction and fixed-price selftender offers and open market share repurchases", The Journal of Finance, 1991, page 12431271.

Dann, L.: "Common stock repurchases: an analysis of returns to bondholders and stockholders", Journal of Financial Economics, 1981, page 113-138.

Davidson, R. and MacKinnon, J.G.: "Estimation and inference in econometrics", Oxford University Press, New York, 1993.

Davis, A.H.R. and Pinches, G.E.: "Canadian financial management", Third edition, Addison-Wesley Publications Limited, Don Mills (Ontario), 1997.

DeAngelo, H., DeAngelo, L. and Skinner, D.: "Special dividends and the evolution of dividend signaling", Journal of Financial Economics, 2000, page 309-354.

De Jong, A. and Van Dijk, R.: "Determinants of leverage and agency problems", Working Paper, Tilburg University, January 2001.

Dittmar, A.K.: "Why do firms repurchase stock?", Journal of Business, 2000, page 331-355.

Easterbrook, F.H.: "Two agency-cost explanations of dividends", American Economic Review, 1984, page 650-659.

Eckbo, B.E. and Verma, S.: "Managerial shareownership, voting power, and cash dividend policy", Journal of Corporate Finance 1, 1994, page 33-62.

Fenn, G.W. and Liang, N.: "Corporate payout policy and managerial stock incentives", Journal of Financial Economics, 2001, 45-72. 
Ikenberry, D., Lakonishok, J. and Vermaelen, T.: "Market underreaction to open market share repurchases", Journal of Financial Economics 39, 1995, page 181-208.

Ikenberry, D., Lakonishok, J. and Vermaelen, T.: "Stock repurchases in Canada: Performance and strategic trading", The Journal of Finance, 2000, 2373-2398.

Jagannathan, M., Stephens, C.P. and Weisbach, M.S.: "Financial flexibility and the choice between dividends and stock repurchases", Journal of Financial Economics, 2000, page 355-384.

Jensen, M.C.: "Agency costs of free cash flow, corporate finance, and takeovers", American Economic Review, 1986, page 323-329.

Jog, V.M. and Srivastava, A.K.: "Corporate financial decision making in Canada", Canadian Journal of Administrative Sciences, 1994, page 156-176.

Jolls, C.: "Stock repurchases and incentive compensation", NBER Working Paper, 1998, no. 6467.

Judge, G.G., Carter Hill, R., Griffiths, W.E., Lütkepohl, H. and Lee, T.C.: "Introduction to the theory and practice of econometrics", John Wiley \& Sons Inc., Canada, 1988.

Jung, K., Kim, Y. and Stulz, R.: "Timing, investment opportunities, managerial discretion, and the security issue design", Journal of Financial Economics, 1996, page 159-185.

Kochhar, R.: "Explaining firm capital structure: the role of agency theory vs. transaction cost economics", Strategic Management Journal, 1996, page 713-728.

Kochhar, R. and Hitt, M.A.: "Linking corporate strategy to capital structure: diversification strategy, type and source of financing", Strategic Management Journal, 1998, page 601-610.

La Porta, R., Lopez-de-Silanes, F., Shleifer, A. and Vishny, R.W.: "Agency problems and dividend policies around the world", The Journal of Finance, 2000, 1-34.

Lakonishok, J. and Vermaelen, T.: "Anomalous price behavior around repurchase tender offers", The Journal of Finance, 1990, page 455-477.

Lambert, R., Lanen, W. and Larcker, D.: "Executive stock option plans and corporate dividend policy", Journal of Financial and Quantitative Analysis 24, 1989, page 409-425.

Lasfer, M.A.: "Share repurchases in Europe: Why is the market underreacting in the UK?", Working Paper, City University Business School, 2000.

Lease, R., Kose, J., Kalay, A., Loewenstein, U. and Sarig, O.: "Dividend policy: its impact on firm value", Harvard Business Press, 1999.

Lease, R., Lewellen, W. and Schlarbaum, G.: "Market segmentation: Evidence on the individual investor", Financial Analysts Journal, 1976, page 53-60.

Li, K. and McNally, W.: "Information signalling or agency conflicts: What explains Canadian open market share repurchases?", Working Paper, University of British Columbia, February 1999.

Lintner, J.: "Distribution of incomes of corporations among dividends, retained earnings and taxes", American Economic Review, 1956, page 97-113.

Mallar, C.D.: "The estimation of simultaneous probability models", Econometrica 45, 1977, page $1717-1722$.

McCarthy, P.S. and Tay, R.S.: "New vehicle consumption and fuel efficiency: a nested logit approach", Transportation Research. Part E: Logistics and Transportation Review 34, 1998, 39-51.

Miller, M. and Modigliani, F.: "Dividend policy, growth and the valuation of shares", Journal of Business, 1961, page 411-433.

Miller, M.H. and Rock, K.: "Dividend policy under asymmetric information, The Journal of Finance, 1985, page 1031-1052. 
Murphy, K.J.: "Executive compensation", Working Paper, University of Southern California, April 1998.

Morey, E.R.: "Two rums uncloaked: Nested-logit models of site choice and nested-logit models of participation and site choice", Working Paper University of Colorado, 1997.

Morey, E.R., Rowe, R.D., and Watson, M.: "A repeated nested-logit model of Atlantic salmon fishing", American Journal of Agricultural Economics 75, 1993, 578-592.

Nelson, F. and Olson, L.: "Specification and estimation of a simultaneous equation model with limited dependent variables", International Economic Review 19, 1978, page 695-709.

Nohel, T. and Tarhan, V.: "Share repurchases and firm performance: new evidence on the agency theory of free cash flow", Journal of Financial Economics, 1998, page 187-222.

Ross, S.A., Westerfield, R.W., Jordan, B.D. and Roberts, G.S.: "Fundamentals of corporate finance: Canadian edition", third edition, Irwin, 1999.

Russell, R.J. and Wells, P.A.: "Predictors of happiness in married couples", Personality and Individual Differences 17, 1994, 313-321.

Sapienza, H.J. and Korsgaard, M.A.: "Procedural justice in entrepreneurship-investor relations", Academy of Management Journal 39, 1996, 544-574.

Shefrin, H.M. and Statman, M.: "Explaining investor preference for cash dividends", Journal of Financial Economics, 1984, page 253-282.

Stephens, C.P. and Weisbach, M.S.: "Actual share reacquisitions in open-market repurchase programs", The Journal of Finance, 1998, page 313-333.

Stone, M.: "Comments on model selection criteria of Akaike and Schwarz", Journal of the Royal Statistical Society B, 1979, 241-278.

Stratmann, T.: "The effects of logrolling on congresssional voting", American Economic Review 82, 1992, 1162-1176.

Titman, S. and Wessels, R.: "The determinants of capital structure choice", The Journal of Finance, 1988, page 1-19.

Vermaelen, T.: "Common stock repurchases and market signalling", Journal of Financial Economics, 1981, page 138-183.

Vermaelen, T.: "Repurchase tender offers, signaling, and managerial incentives", Journal of Financial and Quantitative Analysis, 1984, page 163-181. 
Figure 1: Decision-making trees

Model I: Unrelated decisions

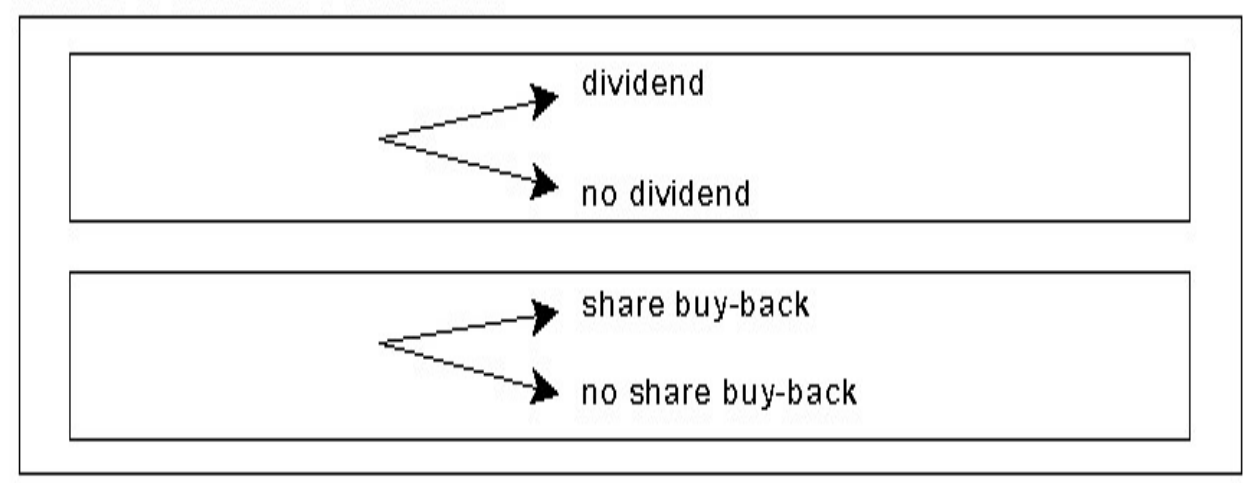

Model II: Related decisions

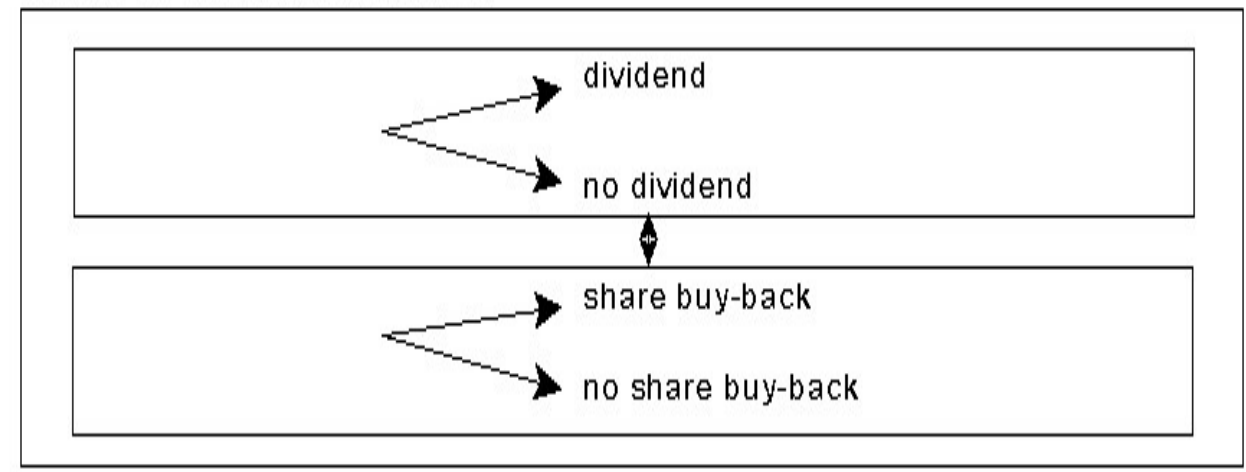

Model III: Sequential decisions

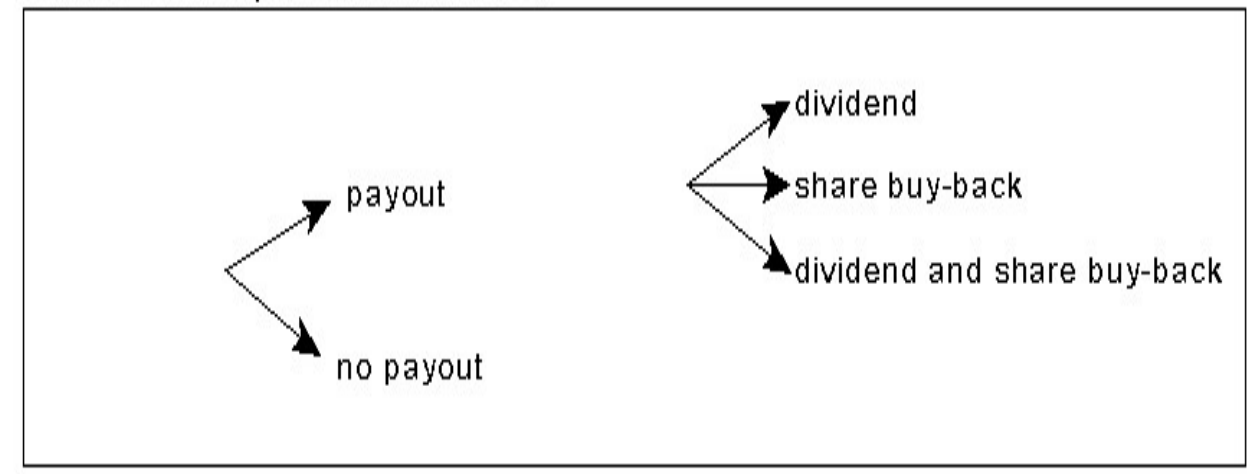


Table 1: Hypotheses on dividend and share buy-back policies of Canadian firms

Panel A: Direct hypotheses

\begin{tabular}{|c|c|c|c|c|}
\hline Variable & $\begin{array}{c}\text { Models I/II: } \\
\text { Dividend/no dividend } \\
\text { (2) }\end{array}$ & $\begin{array}{c}\text { Models I/II: } \\
\text { SBB/no SBB } \\
\text { (3) }\end{array}$ & $\begin{array}{c}\text { Model III: } \\
\text { Payout/no payout } \\
\text { (4) }\end{array}$ & $\begin{array}{c}\text { Model III: if payout: } \\
\text { only div/only SBB/ } \\
\text { div and SBB } \\
\text { (5) }\end{array}$ \\
\hline Dividend paying & & - & & \\
\hline SBB in last three years & - & & & \\
\hline Free cash flow & & & + & \\
\hline Underpricing & & + & & \\
\hline Transaction costs firm & & & - & \\
\hline Asym.info amongst outsiders & & & & Div,+ SBB - \\
\hline Overinvestment & & & $+/-$ & \\
\hline Managerial shareholdings & & & - & \\
\hline Managerial option plans & - & + & & \\
\hline Tax preference for dividends & + & & & \\
\hline Behavioral preference for dividends & + & & & \\
\hline Tax preference for SBBs & & + & & \\
\hline Transaction costs preference stockholders & + & & & \\
\hline Clientele, public corporations & + & & & \\
\hline Clientele, small investors & + & & & \\
\hline
\end{tabular}


Table 1: Hypotheses (Continued)

Panel B: Direct and indirect hypotheses (indirect hypotheses are in parentheses)

\begin{tabular}{|c|c|c|c|c|}
\hline Variable & $\begin{array}{c}\text { Models I/II: } \\
\text { Dividend/no dividend } \\
(2) \\
\end{array}$ & $\begin{array}{c}\text { Models I/II: } \\
\text { SBB/no SBB } \\
(3) \\
\end{array}$ & $\begin{array}{c}\text { Model III: } \\
\text { Payout/no payout } \\
(4) \\
\end{array}$ & $\begin{array}{l}\text { Model III: if payout: } \\
\text { only div/only SBB/ } \\
\text { div and SBB } \\
(5)\end{array}$ \\
\hline Dividend paying & & - & & \\
\hline SBB in last three years & - & & & \\
\hline Free cash flow & $(+)$ & $(+)$ & + & $(=)$ \\
\hline Underpricing & & + & $(+)$ & $(\mathrm{s}=\mathrm{b}>\mathrm{d})$ \\
\hline Transaction costs firm & $(-)$ & $(-)$ & - & $(=)$ \\
\hline Asym.info amongst outsiders & $(+)$ & $(-)$ & & $\mathrm{d}>\mathrm{s}(\mathrm{d}>\mathrm{b}>\mathrm{s})$ \\
\hline Overinvestment & $(+/-)$ & $(+/-)$ & $+/-$ & $(=)$ \\
\hline Managerial shareholdings & $(-)$ & $(-)$ & - & $(=)$ \\
\hline Managerial option plans & - & + & $(-/+)$ & $(s>b>d)$ \\
\hline Tax preference for dividends & + & & $(+)$ & $(d=b>s)$ \\
\hline Behavioral preference for dividends & + & & $(+)$ & $(d=b>s)$ \\
\hline Tax preference for SBBs & & + & $(+)$ & $(\mathrm{s}=\mathrm{b}>\mathrm{d})$ \\
\hline Transaction costs preference stockholders & + & & $(+)$ & $(d=b>s)$ \\
\hline Clientele, public corporations & + & & $(+)$ & $(d=b>s)$ \\
\hline Clientele, small investors & + & & $(+)$ & $(d=b>s)$ \\
\hline
\end{tabular}

The table includes the hypotheses that are tested in the paper. Direct positive "+" and negative "-" relations are indicated. Indirect relations are in parentheses.

Dividends are indicated as "d", share buy-backs as "s" and dividends and share buy-backs together as "b" (both). If the occurrence of the two methods of

payments is equally likely, it is indicated as "=". If one method of payment is more likely than another, it is indicated as " $>$ ", respectively as "<". 
Table 2: Summary statistics on dividend and share buy-back policies of Canadian firms based on 191 completed questionnaires of non-financial firms on the Toronto Stock Exchange

\begin{tabular}{|c|c|c|c|c|c|c|c|c|c|c|c|c|c|c|c|}
\hline \multirow[b]{2}{*}{ variable } & & \multicolumn{2}{|c|}{$\begin{array}{l}\text { (1) } \\
\text { All firms }\end{array}$} & \multicolumn{2}{|c|}{$\begin{array}{l}\text { (2) } \\
\text { Dividend }\end{array}$} & \multicolumn{2}{|c|}{$\begin{array}{l}\text { (3) } \\
\text { No dividend }\end{array}$} & \multicolumn{2}{|c|}{$\begin{array}{l}\text { (4) } \\
\text { (2) vs. (3) }\end{array}$} & \multicolumn{2}{|c|}{$\begin{array}{l}\text { (5) } \\
\text { Share buy-back }\end{array}$} & \multicolumn{2}{|c|}{$\begin{array}{l}(6) \\
\text { No share } \\
\text { buy-back }\end{array}$} & \multicolumn{2}{|c|}{$\begin{array}{l}(7) \\
(5) \text { vs. (6) }\end{array}$} \\
\hline & $\operatorname{tion}(\mathrm{s})$ & mean & (st.dev.) & mean & (st.dev.) & mean & st.dev.) & diff. ( & $p$-value) & mean( & (st.dev.) & mean & st.dev.) & differ & ence ( $p$-value) \\
\hline $\begin{array}{l}\text { Dividend paying } \\
\text { SBB in last three years } \\
\text { Free cash flow } \\
\text { Underpricing } \\
\text { Transaction costs firm } \\
\text { Asym.info mgt. versus outsiders } \\
\text { Asym.info amongst outsiders } \\
\text { Overinvestment } \\
\text { Managerial shareholdings } \\
\text { Managerial option plans } \\
\text { Tax preference for dividends } \\
\text { Behavioral pref. for dividends } \\
\text { Tax preference for SBB } \\
\text { Transaction costs pref. for payout } \\
\text { Clientele, retired persons } \\
\text { Clientele, public corporations } \\
\text { Clientele, small investors }\end{array}$ & $\begin{array}{l}20 \\
21 \\
2,8 \\
1 \\
9 \\
3 \\
18,19 \\
6,7 \\
4 \\
5 \\
10,11 \\
14,16 \\
12,13 \\
17 \\
22 \\
23 \\
24\end{array}$ & $\begin{array}{l}0.41 \\
0.35 \\
2.89 \\
4.42 \\
3.47 \\
5.29 \\
5.27 \\
3.00 \\
3.88 \\
3.35 \\
3.00 \\
2.90 \\
2.62 \\
3.06 \\
1.86 \\
2.59 \\
2.76\end{array}$ & $\begin{array}{l}(1.45) \\
(1.74) \\
(1.52) \\
(1.30) \\
(1.17) \\
(1.29) \\
(1.92) \\
(1.14) \\
(1.57) \\
(1.33) \\
(1.44) \\
(1.32) \\
(2.24) \\
(2.50) \\
(2.33)\end{array}$ & $\begin{array}{l}1.00 \\
0.38 \\
3.24 \\
4.17 \\
2.97 \\
5.07 \\
5.24 \\
2.84 \\
3.90 \\
3.01 \\
3.74 \\
3.55 \\
2.87 \\
3.19 \\
1.96 \\
2.69 \\
2.71\end{array}$ & $\begin{array}{l}(1.50) \\
(1.77) \\
(1.46) \\
(1.29) \\
(1.21) \\
(1.19) \\
(2.02) \\
(1.32) \\
(1.36) \\
(0.99) \\
(1.42) \\
(1.28) \\
(2.21) \\
(2.52) \\
(2.36)\end{array}$ & $\begin{array}{l}0.00 \\
0.32 \\
2.64 \\
4.59 \\
3.81 \\
5.44 \\
5.29 \\
3.11 \\
3.87 \\
3.60 \\
2.47 \\
2.41 \\
2.45 \\
2.97 \\
1.80 \\
2.52 \\
2.80\end{array}$ & $\begin{array}{l}(1.38) \\
(1.70) \\
(1.47) \\
(1.30) \\
(1.14) \\
(1.34) \\
(1.86) \\
(1.42) \\
(1.50) \\
(1.33) \\
(1.45) \\
(1.34) \\
(2.26) \\
(2.49) \\
(2.32)\end{array}$ & $\begin{array}{r}- \\
0.07 \\
0.60 \\
-0.42 \\
-0.84 \\
-0.38 \\
-0.04 \\
-0.27 \\
0.03 \\
-0.60 \\
1.26 \\
1.13 \\
0.43 \\
0.22 \\
0.17 \\
0.17 \\
-0.09\end{array}$ & $\begin{array}{l}(0.348) \\
(0.005)^{* *} \\
(0.099) \\
(0.000)^{* *} \\
(0.051) \\
(0.799) \\
(0.158) \\
(0.919) \\
(0.004)^{* *} \\
(0.000)^{* *} \\
(0.000)^{* *} \\
(0.051) \\
(0.258) \\
(0.617) \\
(0.645) \\
(0.791)\end{array}$ & $\begin{array}{l}0.45 \\
1.00 \\
3.26 \\
4.65 \\
3.77 \\
5.20 \\
5.08 \\
2.86 \\
3.98 \\
3.52 \\
3.16 \\
3.10 \\
3.12 \\
3.35 \\
2.14 \\
2.67 \\
2.97\end{array}$ & $\begin{array}{l}(1.52) \\
(1.69) \\
(1.39) \\
(1.30) \\
(1.11) \\
(1.15) \\
(1.94) \\
(1.44) \\
(1.49) \\
(1.20) \\
(1.54) \\
(1.27) \\
(2.34) \\
(2.42) \\
(2.25)\end{array}$ & $\begin{array}{l}0.38 \\
0.00 \\
2.69 \\
4.30 \\
3.31 \\
5.34 \\
5.37 \\
3.07 \\
3.82 \\
3.26 \\
2.91 \\
2.77 \\
2.36 \\
2.91 \\
1.72 \\
2.55 \\
2.65\end{array}$ & $\begin{array}{l}(1.39) \\
(1.76) \\
(1.56) \\
(1.31) \\
(1.19) \\
(1.35) \\
(1.92) \\
(1.40) \\
(1.61) \\
(1.37) \\
(1.33) \\
(1.32) \\
(2.18) \\
(2.54) \\
(2.37)\end{array}$ & $\begin{array}{r}0.07 \\
- \\
0.57 \\
0.35 \\
0.46 \\
-0.14 \\
-0.28 \\
-0.22 \\
0.16 \\
0.26 \\
0.26 \\
0.33 \\
0.76 \\
0.44 \\
0.42 \\
0.11 \\
0.32\end{array}$ & $\begin{array}{l}(0.348) \\
(0.010)^{* *} \\
(0.184) \\
(0.051) \\
(0.488) \\
(0.109) \\
(0.270) \\
(0.581) \\
(0.228) \\
(0.292) \\
(0.103) \\
(0.001)^{* *} \\
(0.028)^{*} \\
(0.222) \\
(0.764) \\
(0.365)\end{array}$ \\
\hline Observations & & 191 & & 78 & & 113 & & & & 66 & & 125 & & & \\
\hline
\end{tabular}


Table 2: Summary statistics (continued)

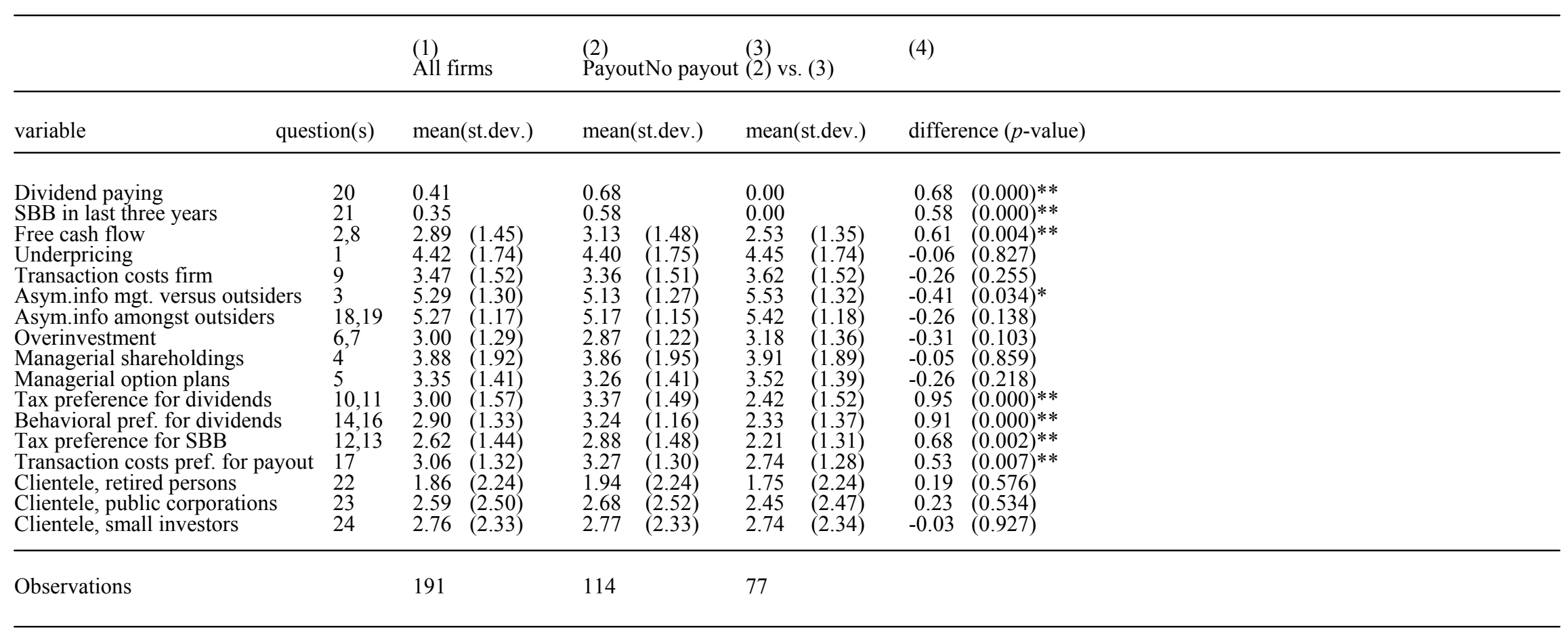


Table 2: Summary statistics (continued)

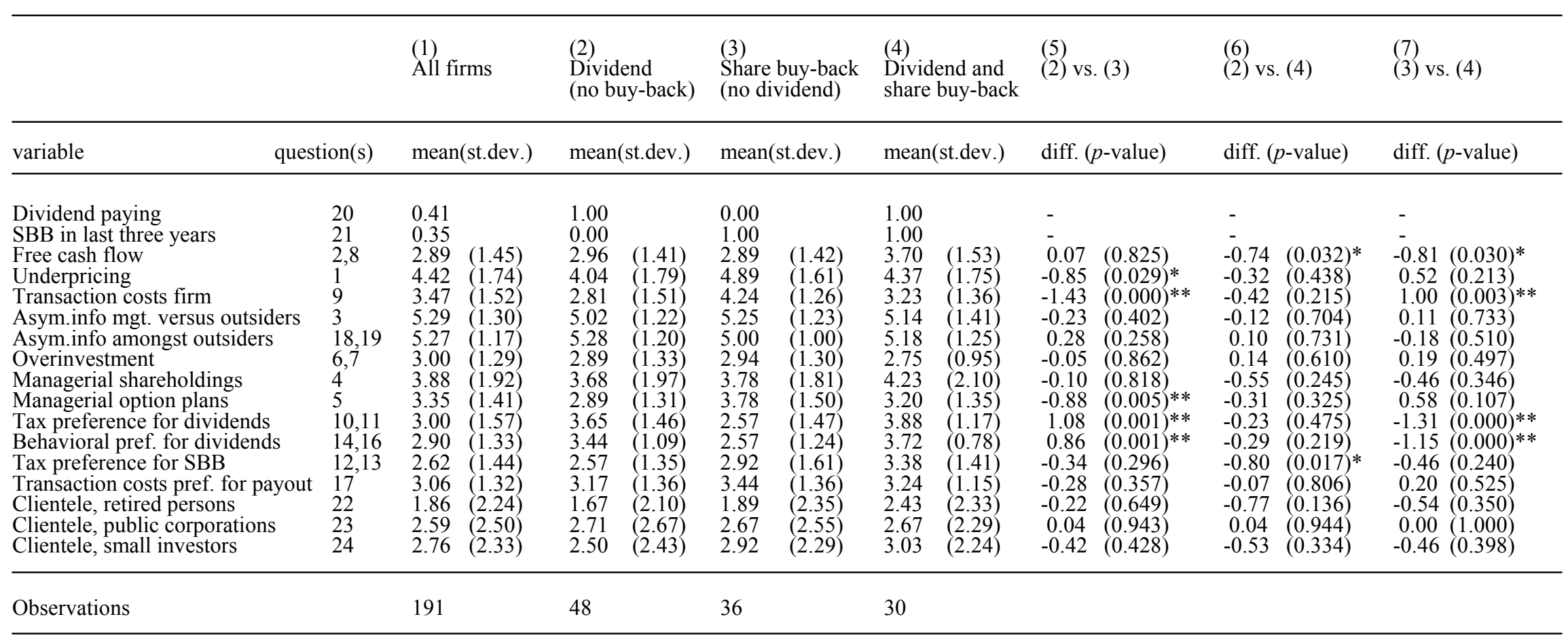

The table reports the summary statistics of the 191 completed questionnaires of non-financial companies on the Toronto Stock Exchange. The number of the question refers to Appendix $\mathrm{C}$ where the questionnaire is presented. Dividend payment and share buy-back $(\mathrm{SBB})$ were either answered confirmative $(=1)$ or non-confirmative $(=0)$. All other questions were answered on a scale from 1 (non confirmative) to 7 (confirmative). In questions 22 to 24 we asked for the relative representation of groups of shareholders of a firm. Some variables are measured using two or three questions. For such variables we present the average of the relevant questions. Over the sample we present all averages and standard deviations (in parentheses). We also present results for different subsamples. In addition, the differences between subsamples and the $p$ values (in brackets) are reported. The symbol ' $* *$ ' denotes that the estimate is significant at the $1 \%$ level. The symbol '*' denotes the $5 \%$ significance level. 
Table 3: Results of the single logit regressions on dividend and share buy-back policies of Canadian firms (model I)

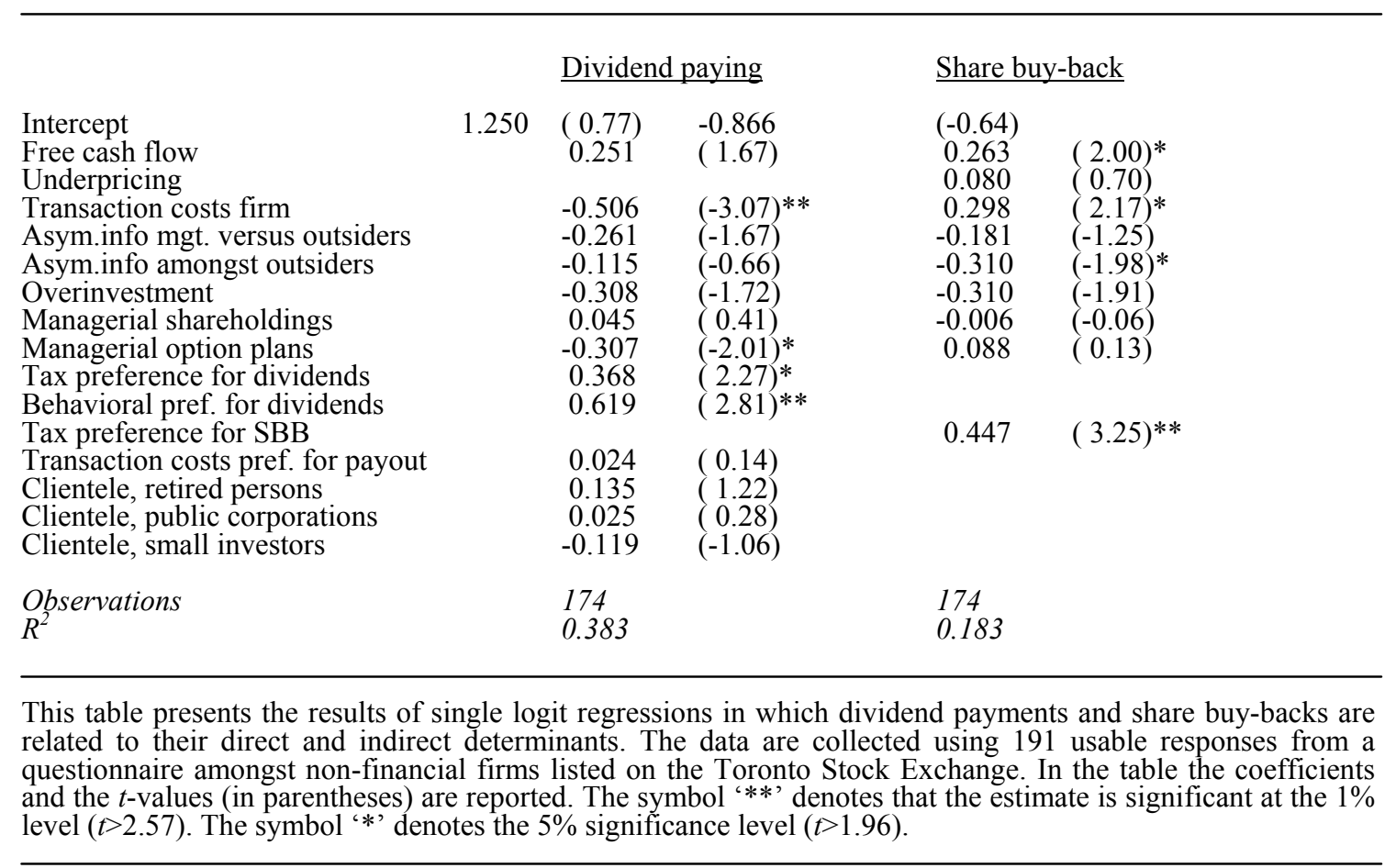


Table 4: Results of the simultaneous logit regressions on dividend and share buy-back policies of Canadian firms (model II)

\begin{tabular}{|c|c|c|c|c|c|}
\hline \multirow{16}{*}{$\begin{array}{l}\text { Intercept } \\
\text { Dividend paying } \\
\text { Share buy-back } \\
\text { Free cash flow } \\
\text { Underpricing } \\
\text { Transaction costs firm } \\
\text { Asym.info mgt. versus outsiders } \\
\text { Asym.info amongst outsiders } \\
\text { Overinvestment } \\
\text { Managerial shareholdings } \\
\text { Managerial option plans } \\
\text { Tax preference for dividends } \\
\text { Behavioral pref. for dividends } \\
\text { Tax preference for SBB } \\
\text { Transaction costs pref. for payout } \\
\text { Clientele, retired persons } \\
\text { Clientele, public corporations } \\
\text { Clientele, small investors }\end{array}$} & & \multicolumn{2}{|c|}{ Dividend paying } & \multicolumn{2}{|c|}{ Share buy-back } \\
\hline & \multirow[t]{15}{*}{0.894} & $(0.43)$ & -0.869 & \multirow{2}{*}{$\begin{array}{c}(-0.55) \\
0.001\end{array}$} & \multirow{2}{*}{$(0.01)$} \\
\hline & & -0.272 & $(-0.79)$ & & \\
\hline & & 0.361 & $(1.51)$ & \multirow{8}{*}{$\begin{array}{r}0.263 \\
0.080 \\
0.299 \\
-0.181 \\
-0.310 \\
-0.311 \\
-0.006 \\
0.088\end{array}$} & \multirow{8}{*}{$\begin{array}{l}(1.69) \\
(0.63) \\
(1.77) \\
(-1.09) \\
(-1.81) \\
(-1.69) \\
(-0.06) \\
(0.58)\end{array}$} \\
\hline & & -0.434 & $(-1.96)^{*}$ & & \\
\hline & & -0.305 & $(-1.49)$ & & \\
\hline & & -0.181 & $(-0.77)$ & & \\
\hline & & -0.398 & $(-1.53)$ & & \\
\hline & & 0.038 & $(0.29)$ & & \\
\hline & & -0.291 & $(-1.18)$ & & \\
\hline & & 0.398 & $(1.86)$ & & \\
\hline & & 0.620 & $(2.30)^{*}$ & \multirow{5}{*}{0.447} & \multirow{5}{*}{$(2.82)^{* *}$} \\
\hline & & 0.091 & $(0.39)$ & & \\
\hline & & 0.151 & $(1.11)$ & & \\
\hline & & 0.031 & $(0.28)$ & & \\
\hline & & -0.108 & $(-0.80)$ & & \\
\hline $\begin{array}{l}\text { Observations } \\
R^{2}\end{array}$ & & \multicolumn{2}{|l|}{$\begin{array}{l}174 \\
0.386\end{array}$} & \multicolumn{2}{|l|}{$\begin{array}{l}174 \\
0.183\end{array}$} \\
\hline \multicolumn{6}{|c|}{$\begin{array}{l}\text { This table presents the results of simultaneous logit regressions in which dividend payments and share buy- } \\
\text { backs are related to their direct and indirect determinants. The data are collected using } 191 \text { usable responses } \\
\text { from a questionnaire amongst non-financial firms listed on the Toronto Stock Exchange. In the table the } \\
\text { coefficients and the } t \text {-values (in parentheses) are reported. The symbol '**' denotes that the estimate is } \\
\text { significant at the } 1 \% \text { level }(t>2.57) \text {. The symbol '*' denotes the } 5 \% \text { significance level }(t>1.96) \text {. }\end{array}$} \\
\hline
\end{tabular}


Table 5: Results of the nested logit regressions on dividend and share buy-back policies of Canadian firms (model III)

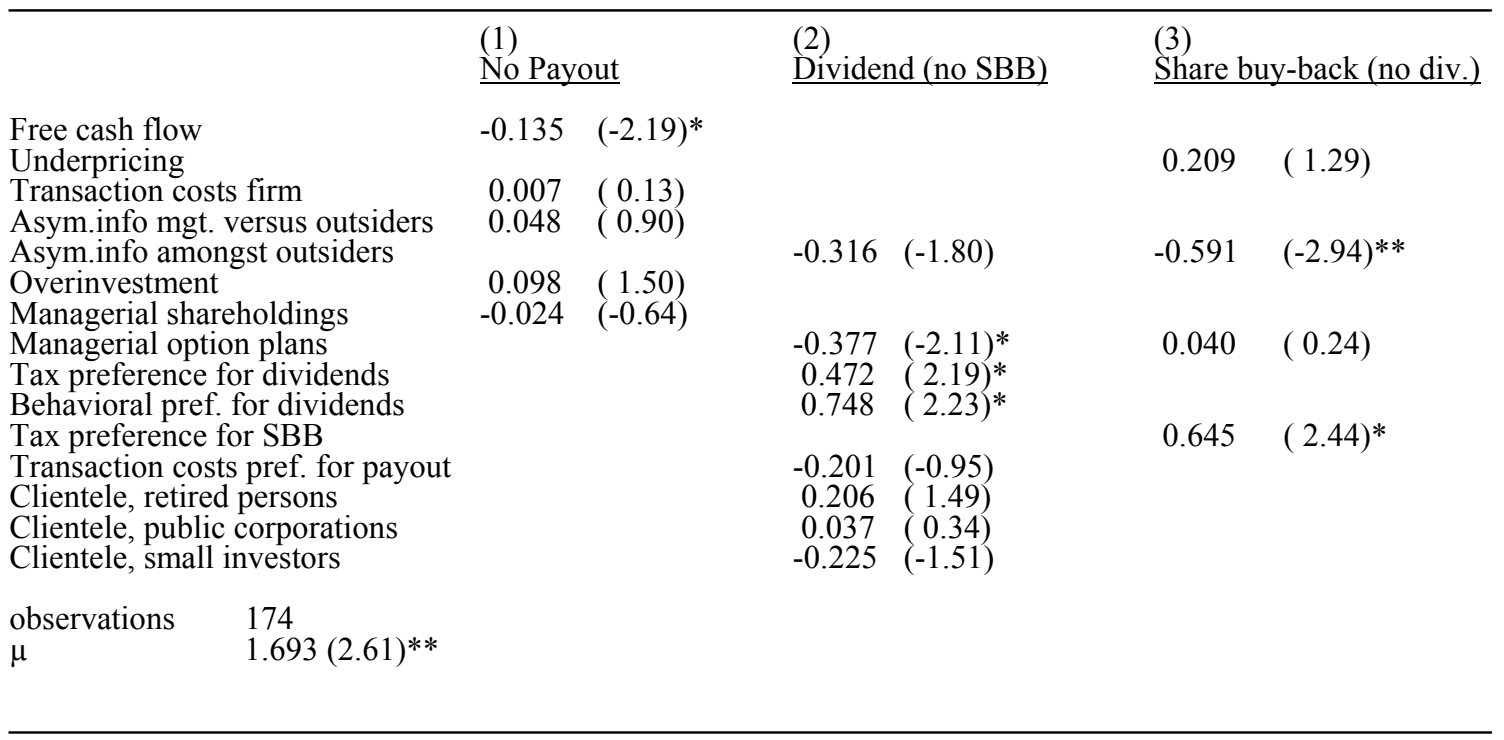

This table presents the results of nested logit regressions. In the first stage of these regressions payout is related to its direct determinants. In the second stage the form of the payout is related to their direct determinants. The data are collected using 191 usable responses from a questionnaire amongst non-financial firms listed on the Toronto Stock Exchange. The variables that are allowed to affect the likelihood on a dividend and SBB are the union of the variables that are allowed to affect dividends (no SBBs) and to affect SBBs (no dividends). The parameters are restricted to be equal to those for the single instruments cases. The parameter $\mu$ is a scaling parameter as given by equation (9). In the table the coefficients and the $t$-values (in parentheses) are reported. The symbol ' $* *$ ' denotes that the estimate is significant at the $1 \%$ level $(t>2.57)$. The symbol '*' denotes the $5 \%$ significance level $(t>1.96)$. 
Table 6: Comparison of the logit regression models on dividend and share buy-back policies of Canadian firms

\section{Panel A}

Separate logit (Table 3): 96 correct (55\%)

\begin{tabular}{lllll}
\multirow{2}{*}{ Predicted } & \multicolumn{2}{l}{ Actual } & & \\
Div & SBB & Both & No payout \\
Dividend & 27 & 3 & 9 & 12 \\
& {$[60.0]$} & {$[9.1]$} & {$[33.3]$} & {$[17.4]$} \\
SBB & 0 & 7 & 3 & 5 \\
& {$[0.0]$} & {$[21.2]$} & {$[11.1]$} & {$[7.2]$} \\
Both & 4 & 3 & 11 & 1 \\
& {$[8.9]$} & {$[9.1]$} & {$[40.7]$} & {$[1.4]$} \\
No payout & 14 & 20 & 4 & 51 \\
& {$[31.1]$} & {$[60.6]$} & {$[14.8]$} & {$[73.9]$} \\
Total & 45 & 33 & 27 & 69 \\
& {$[100]$} & {$[100]$} & {$[100]$} & {$[100]$}
\end{tabular}

Multinomial logit (Appendix D.): 95 correct (55\%)

\begin{tabular}{|c|c|c|c|c|}
\hline Pre & $\frac{\text { Actua }}{\text { Div }}$ & SBB & Both & No pave \\
\hline Dividend & $\begin{array}{l}27 \\
{[60.0]}\end{array}$ & $\begin{array}{l}3 \\
{[9.1]}\end{array}$ & $\begin{array}{l}9 \\
{[33.3]}\end{array}$ & $\begin{array}{l}12 \\
{[17.4]}\end{array}$ \\
\hline SBB & & 6 & $\begin{array}{l}3 \\
{[111}\end{array}$ & 5 \\
\hline Both & & & 11 & 1 \\
\hline No payout & $\begin{array}{l}{[8.9]} \\
14\end{array}$ & $\begin{array}{l}{[9.1]} \\
21 \\
{[636}\end{array}$ & $\begin{array}{l}{[40.7]} \\
4 \\
{[148}\end{array}$ & $\begin{array}{l}{[1.4]} \\
51\end{array}$ \\
\hline Total & $\begin{array}{l}45 \\
{[100]}\end{array}$ & $\begin{array}{l}33 \\
{[100]}\end{array}$ & $\begin{array}{l}27 \\
{[100]}\end{array}$ & $\begin{array}{l}69 \\
{[100]}\end{array}$ \\
\hline
\end{tabular}

\begin{tabular}{lllll}
\multicolumn{5}{l}{ Simultaneous logit (Table 4): 99 correct (57\%) } \\
\multirow{2}{*}{ Predicted } & Actual & \multicolumn{4}{l}{} \\
\cline { 2 - 4 } Dividend & Div & SBB & Both & No payout \\
& 30 & 3 & 9 & 12 \\
SBB & {$[66.7]$} & {$[9.1]$} & {$[33.3]$} & {$[17.4]$} \\
& 0 & 7 & 3 & 5 \\
Both & {$[0.0]$} & {$[21.2]$} & {$[11.1]$} & {$[7.2]$} \\
& 4 & 3 & 11 & 1 \\
No payout & {$[8.9]$} & {$[9.1]$} & {$[40.7]$} & {$[1.4]$} \\
\multirow{2}{*}{ Total } & 11 & 20 & 4 & 51 \\
& {$[24.4]$} & {$[60.6]$} & {$[14.8]$} & {$[73.9]$} \\
& 45 & 33 & 27 & 69 \\
& {$[100]$} & {$[100]$} & {$[100]$} & {$[100]$}
\end{tabular}

Nested logit (Table 5): 88 correct (51\%)

\begin{tabular}{|c|c|c|c|c|}
\hline Predicted & $\frac{\text { Actual }}{\text { Div }}$ & SBB & Both & No nayout \\
\hline Dividend & 17 & & 9 & 8 \\
\hline SBB & 1 & & $l^{[35 . J]}$ & $\begin{array}{l}111.0] \\
1\end{array}$ \\
\hline Both & ${ }^{[}[2.2]$ & $\begin{array}{l}{[15.2]} \\
7\end{array}$ & & $\begin{array}{l}{[1.4]} \\
5\end{array}$ \\
\hline No payout & $\begin{array}{l}{[17.8]} \\
19 \\
\end{array}$ & $\begin{array}{l}{[21.2]} \\
20 \\
{[606]}\end{array}$ & $\begin{array}{l}{[37.0]} \\
6 \\
{[22.2]}\end{array}$ & $\begin{array}{l}{[5.8]} \\
56 \\
{[81.27}\end{array}$ \\
\hline Total & $\begin{array}{l}45 \\
{[100]}\end{array}$ & $\begin{array}{l}33 \\
{[100]}\end{array}$ & $\begin{array}{l}27 \\
{[100]}\end{array}$ & $\begin{array}{l}69 \\
{[100]}\end{array}$ \\
\hline
\end{tabular}

\section{Panel B}

Percentage predicted correctly Likelihood

AIC criterion

Schwarz criterion

Number of parameters

\begin{tabular}{|c|c|}
\hline Multinomial logit & Nested logit \\
\hline $55 \%$ & $51 \%$ \\
\hline 177.8 & 191.8 \\
\hline 152.8 & 172.9 \\
\hline 149.8 & 170.6 \\
\hline & 21 \\
\hline
\end{tabular}




\section{Table 6: continued}

Panel A contains comparisons between actual and predicted outcomes for four different logit models. Percentages are between brackets. Panel B includes statistics to compare the fit of the multinomial and nested logit models. The data are collected using 191 usable responses from a questionnaire amongst non-financial firms listed on the Toronto Stock Exchange. 


\section{Appendix A: The tax treatment of dividends and capital gains under Canadian taxation}

The treatment of dividends and capital gains in the Canadian tax law can best be illustrated using an example from Davis and Pinches (1997). They show the calculation of the after-tax dividends and capital gains for an Ontario investor who receives $\$ 10,000$ in either dividends or capital gains.

Tax treatment of dividends:

Dividends received

$\$ 10,000$

Add: Gross-up at $25 \%$ 2,500

Taxable dividend 12,500

Federal income tax $(0.26 * 12,500)$

3,250

Less: Dividend tax credit $(0.1333 * 12,500)$

1,667

Federal tax payable

Add: Ontario tax $(0.58 * 1.583)$

Total tax

Dividends after taxes $=10,000-2,501=7,499$

Effective tax rate on dividends (total tax/dividends received) $=25.01 \%$

Tax treatment of capital gains:

Capital gains received

Federal income tax $(0.26 * 0.75 * 10,000)$

Add: Ontario tax $(0.58 * 1,950)$
\$ 10,000

1,950

1,131

Total tax

Dividends after taxes $=10,000-3,081=6,919$

Effective tax rate on dividends (total tax/dividends received) $=30.81 \%$ 


\section{Appendix B: The logit models}

\section{B.1. Single logit equations}

One of the choices that we model, is between dividend $(D)$ and no dividend (ND). Another choice is between share buy-back (S) and no share buy-back (NS). The choice between the alternatives within each process is based on the relative attractiveness, which can be modeled by utility functions. In this appendix we explain the binary response models that are used to model such dichotomous decisions by means of the dividends versus no-dividend model. Substitution of the subscript $S$ for $D$ gives the share buy back process. For firm $i$ the total utility $U_{i D}$ associated to paying dividend is,

$$
U_{i D}=v_{i D}+e_{i D}
$$

where $v_{i D}$ denotes the systematic component and $e_{i D}$ the error term, which is unknown to the researcher and known to the firm. The idea behind the use of binary response models to describe the dividend policy is that a firm $i$ pays dividends only if $U_{i D}$ is higher than a particular threshold. In general, a linear specification is assumed for the systematic part, i.e.

$$
v_{i D}=\sum_{k} x_{i D k} \cdot b_{k}^{D} \equiv x_{i D}{ }^{\prime} \cdot \beta_{D} \text {, }
$$

where $b_{k}{ }^{D}$ are parameters and $x_{i D k}$ firm characteristics that are potentially related to dividend payout. The vectors $x_{i D}$ and $\beta_{D}$ contain $x_{i D k}$ and $b_{\mathrm{k}}{ }^{\mathrm{D}}$, respectively. The standard logit model assumes that the error terms are independently and identically Gumbel distributed. Given this assumption, it can be derived that the probability $P_{i}$ that a firm $i$ chooses for the payment of dividends is:

$$
P_{i}(D)=\frac{\exp \left(v_{i D}\right)}{1+\exp \left(v_{i D}\right)} .
$$

The probability $P_{i}(N D)$ equals $1-P_{i}(D)$. Estimates for $b_{k}{ }^{D}$ and inference can be obtained by standard maximum likelihood methods. As stated before, in a similar way probabilities derived for $P_{i}(S)$ and $1-P_{i}(N S)$.

\section{B.2. Structural logit equation model}

In a structural logit equation model, the standard logit model is extended by incorporating a dividend or share buy back variable in the systematic parts of the two utility functions. Therefore, the utility of dividend payout depends on SBB, and the utility of SBB depends on the dividend payout. The structural-form representation of this model is given by,

$$
\begin{aligned}
& U_{i D}=U_{i S} \cdot \gamma_{D}+x_{i D}{ }^{\prime} \cdot \beta_{D}+e_{i D} \\
& U_{i S}=U_{i D} \cdot \gamma_{S}+x_{i S}{ }^{\prime} \cdot \beta_{S}+e_{i S}
\end{aligned},
$$

where $U_{i D}$ and $U_{i S}$ are the unobserved utilities obtained from dividend payment and share buy-back by firm $i$. The $\gamma_{D}$ and $\gamma_{S}$ are parameters and the $\beta_{D}$ and $\beta_{S}$ are vectors of parameters as before. Exogenous variables are contained in $x_{i D}$ and $x_{i S}$. The error terms are denoted by $e_{i D}$ and $e_{i s}$. The firm knows these error terms, the researcher does not. We only observe whether $U_{i D}$ and $U_{i S}$ are above particular thresholds since we only observe whether the firms pays dividends or not and buys back shares or not. Mallar (1977) examines simultaneous logit equations and shows the relationship between the probability that an event occurs, and the structural-form representation. He argues that a two-stage estimator is appropriate to estimate the system using standard techniques for models with dichotomous variables. In the first stage the parameters of the reducedform representation of (4) are estimated. The estimated parameters are used to obtain consistent estimates $U^{*}{ }_{i D}$ and $U_{i S}^{*}$ for $U_{i D}$ and $U_{i S}$ in the right-hand side of (4). In the second stage, after substitution of the estimates $U^{*}{ }_{i D}$ and $U_{i S}^{*}$ for $U_{i D}$ and $U_{i S}$ in the right-hand side of (4), the structural-equations representation is estimated. If we assume that $e_{i D}$ and $e_{i S}$ follow the Gumbel distribution then standard logit estimators can be used in stage one and two. Note that in stage two the probabilities are similar as in (3), and its analog for the share buy back decision, using, 


$$
\begin{aligned}
& v_{i D}=U_{i S}^{*} \cdot \gamma_{D}+x_{i D}{ }^{\prime} \cdot \beta_{D} \\
& v_{i S}=U_{i D}^{*} \cdot \gamma_{S}+x_{i S}{ }^{\prime} \cdot \beta_{S}
\end{aligned} .
$$

The exact specification of the asymptotic distribution of the parameter estimate is difficult to obtain due to the presence of generated regressors in the second stage, i.e. $U_{i D}$ and $U_{i S}$ (see Nelson and Olson, 1978). This distribution is important for the tests of the statistical significance of the parameter estimates. Amemiya (1979) derives the asymptotic distribution and shows that it depends on the unknown parameters $\gamma_{D}$ and $\gamma_{S}$ and nuisance parameters. We apply the bootstrap method to obtain the distribution of the parameter estimates. Besides simplicity, the advantage of the procedure is that the findings hold for our finite sample. Our bootstrap method draws the error terms in (4) from the Gumbel distribution. In total we obtain 10,000 bootstrap parameter estimates from which we can make inference on the standard errors of our parameter estimates (see Davidson and MacKinnon, 1993).

\section{B.3. Nested logit model}

Let $P N$ and $P Y$ denote the first choice of not paying and paying, respectively. The second choice is described by $S, D$, and $D S$ which denote only share buy-back, only dividend payment and the simultaneous use of both instruments, respectively. Consequently, the choice set is, $C=\{(P N),(P Y, S),(P Y, D),(P Y, D S)\}$. The nested logit model that describes the choice set $C$ has several underlying assumptions, which will be discussed briefly. In addition, we summarize several general properties of the model. The first important underlying assumption is that the attractiveness of choice $c$ in $C$ is described by utility functions,

$$
U_{i c I}=v_{i P Y}+v_{i I}+e_{i P Y}+e_{i I} \text { if } c=P Y
$$

and

$$
U_{i c}=v_{i P N}+e_{i P N} \quad \text { if } \quad c=P N
$$

where $\mathrm{I} \in\{\mathrm{S}, \mathrm{D}, \mathrm{DS}\}, v_{i P N}, v_{i P Y}$ and $v_{i I}$ are the systematic components of the utility function related to pay out and instrument choice, and $e_{i P N}, e_{i P Y}$ and $e_{i I}$ are the error terms of the utility functions. The firms know these error components, the researcher does not. Note that the error components of the utility functions for different I are correlated, which is not the case in the standard logit and multinomial models. Using Ben-Akiva and Lerman (1985) and their assumptions for the distribution of $\left(e_{i P N}, e_{i P Y}, e_{i S}, e_{i D}, e_{i D S}\right)$, we can derive that

$$
\begin{aligned}
& P_{i}(P N)=\frac{\exp \left[v_{i P N}\right]}{\exp \left[v_{i P N}\right]+\exp \left[\left(v_{i P Y}+v_{i P Y}^{*}\right) \mu\right]}, \\
& P_{i}(P Y)=\frac{\exp \left[\left(v_{i P Y}+v_{i P Y}^{*}\right) \mu\right]}{\exp \left[v_{i P N}\right]+\exp \left[\left(v_{i P Y}+v_{i P Y}^{*}\right) \mu\right]},
\end{aligned}
$$

and

$$
P_{i}(I)=\frac{\exp \left[v_{i I}+v_{i P Y}\right]}{\sum_{J=S, D, D S} \exp \left[v_{i J}+v_{i P Y}\right]},
$$

where $\mu$ is a scaling parameter of the distribution of $U_{i c}$ and

$$
v_{i P N}^{*}=\ln \sum_{I} \exp \left(v_{i I}\right)
$$

The next step is to determine the specification of the systematic components in the utility function. As above, we assume that linear specifications are appropriate, i.e.

$$
v_{i P N}=\sum_{k} a_{k} x_{i k}^{P N}, \quad v_{i P Y}=\sum_{k} b_{k} x_{i k}^{P Y} \quad \text { and } \quad v_{i I}=\sum_{k} c_{I k} x_{i k}^{I}
$$

where $a_{k}, b_{k}$ and $c_{I k}$ are parameters and $x_{i k}^{P N}, x_{i k}^{P Y}$ and $x_{i k}^{I}$ are explanatory variables. 


\section{Appendix C: The questionnaire}

Remark: In this questionnaire we want to focus exclusively on cash dividends, thus excluding stock dividends. For this reason we want to ask you to read the term dividend as cash dividend.

Remark: Share buy-back programs include tender offers to all the firm's shareholders, the purchase of stock in the secondary market, and the agreement to buy stock from one or a small group of the firm's major investors.

1 During the last 3 years the stock of my firm has been undervalued for a long time. (1-7, strongly disagree - strongly agree)

2 The internal funds, which are available now and which will become available in the future, are more than sufficient to finance all future profitable projects. (1-7, strongly disagree - strongly agree)

3 Compared to other non-financial firms listed on the TSE, the management of my firm is much more aware of the firm's activities than outsiders are. (1-7, strongly disagree - strongly agree)

4 Compared to other non-financial firms listed on the TSE, the number of shares that the management owns in the firm as a percentage of the total number of shares is: (1-7, very small - very large)

5 Compared to other non-financial firms listed on the TSE, the number of executive stock options/warrants that the management owns in the firm as a percentage of the total number of outstanding shares is: (1-7, very small - very large)

6 In my firm a project is accepted if it is useful in the management's opinion, even if it is expected that this will cause a reduction in the stock price. (1-7, strongly disagree - strongly agree)

$7 \quad$ We avoid cutting capital expenditures if this creates a less pleasant working atmosphere. (1-7, strongly disagree - strongly agree)

8 My firm possesses much cash and other liquid assets for which there is no clear purpose yet. (1-7, strongly disagree - strongly agree)

9 Compared to other firms on the TSE, the average flotation costs for public equity issues are high. (1-7, strongly disagree - strongly agree)

10 Due to income tax reasons my private shareholders have a preference for receiving dividends over selling shares. (1-7, strongly disagree - strongly agree)

11 Due to tax reasons our institutional shareholders have a preference for receiving dividends over selling shares. (1-7, strongly disagree - strongly agree)

12 Due to income tax reasons our private shareholders like us to regularly buy back shares in a share buyback program. (1-7, strongly disagree - strongly agree)

13 Due to tax reasons our institutional shareholders like us to regularly buy back shares in a share buyback program. (1-7, strongly disagree - strongly agree)

14 Apart from taxes and transaction costs, my private shareholders perceive income in the form of dividends more attractive than income in the form of capital gains. (1-7, strongly disagree - strongly agree)

15 Apart from taxes and transaction costs, my institutional shareholders perceive income in the form of dividends more attractive than income in the form of capital gains. (1-7, strongly disagree - strongly agree)

16 My private shareholders prefer to consume from dividends over consuming from capital gains. (1-7, strongly disagree - strongly agree)

17 The transaction costs for selling stocks in order to cash in capital gains are high for my shareholders. (1-7, strongly disagree - strongly agree)

18 Some shareholders of my firm are better aware of the firm's activities than others, because of their large stakes in the firm. (1-7, strongly disagree - strongly agree)

19 Some shareholders of my firm are better aware of the firm's activities than others, because they make more efforts to be informed about the firm's activities. (1-7, strongly disagree - strongly agree)

Remark: In some questions a reference is made to the financial year 1997. This is the financial year ending on December 31, 1997. If your firm has a broken financial year, please give the answer for the financial year that ends in 1997

20 What were the total Dividends Per Share, based on regular dividends, that your firm paid over the financial year 1997? (in Can \$) 
21 How many share buy-back programs did your firm carry out during the last 3 financial years ? ( $1=$ none, $2=$ one, .., $6=$ five, $7=$ more than five)

How well are the following groups of shareholders represented amongst the shareholders of your firm compared with other firms on the TSE? If you don't have any idea at all about the relative size of a certain group of shareholders, you can leave the answer blank.

22 Private persons who are retired (blank or 1-7, very well represented - not represented at all)

23 Public corporations (blank or 1-7, very well represented - not represented at all)

24 Private persons and institutions that you would characterize as small investors (blank or 1-7, very well represented - not represented at all) 


\section{Appendix D: Results of the multinomial logit regressions on dividend and share buy-back policies of Canadian firms}

\begin{tabular}{|c|c|c|c|}
\hline \multirow[b]{2}{*}{ Intercept } & \multicolumn{2}{|c|}{ Dividend (no SBB) } & $\underline{\text { Share buy-back (no div.) }}$ \\
\hline & $(-3.31)^{*}$ & -1.368 & $(-4.76)^{* *}$ \\
\hline Free cash flow & 0.349 & $(1.61)$ & $0.368 \quad(1.95)$ \\
\hline Underpricing & & & $0.135 \quad(0.70)$ \\
\hline Transaction costs firm & -0.779 & $(-3.05) * *$ & $0.466 \quad(2.16)^{*}$ \\
\hline Asym.info mgt. versus outsiders & -0.332 & $(-1.65)$ & $-0.227 \quad(-1.20)$ \\
\hline Asym.info amongst outsiders & -0.130 & $(-0.64)$ & $-0.356 \quad(-1.96)^{*}$ \\
\hline Overinvestment & -0.386 & $(-1.67)$ & $-0.392 \quad(-1.88)$ \\
\hline Managerial shareholdings & 0.087 & $(0.41)$ & $-0.014 \quad(-0.09)$ \\
\hline Managerial option plans & -0.443 & $(-2.02)^{*}$ & $0.135 \quad(0.72)$ \\
\hline Tax preference for dividends & 0.579 & $(2.26)^{*}$ & \\
\hline Behavioral pref. for dividends & 0.813 & $(2.80)^{* *}$ & \\
\hline Tax preference for SBB & & & $0.628(3.17)^{* *}$ \\
\hline Transaction costs pref. for payout & 0.031 & $(0.14)$ & \\
\hline Clientele, retired persons & 0.305 & $(1.20)$ & \\
\hline Clientele, public corporations & 0.063 & $(0.27)$ & \\
\hline Clientele, small investors & -0.269 & $(-1.05)$ & \\
\hline Observations & & & \\
\hline
\end{tabular}

This table presents the results of the multinomial logit regressions in which dividend payments and share buybacks are related to their direct and indirect determinants. The data are collected using 191 usable responses from a questionnaire amongst non-financial firms listed on the Toronto Stock Exchange. The variables that are allowed to affect the likelihood on a dividend and SBB are the union of the variables that are allowed to affect dividends (no SBBs) and to affect SBBs (no dividends). In the table the coefficients and the $t$-values (in parentheses) are reported. The symbol '**' denotes that the estimate is significant at the $1 \%$ level $(t>2.57)$. The symbol '*' denotes $5 \%$ significance level $(t>1.96)$. 